NBER WORKING PAPER SERIES

\title{
DISABILITY INSURANCE AND LABOR MARKET EXIT ROUTES OF OLDER WORKERS IN THE NETHERLANDS
}

\author{
Klaas de Vos \\ Arie Kapteyn \\ Adriaan Kalwij \\ Working Paper 17053 \\ http://www.nber.org/papers/w17053
}

NATIONAL BUREAU OF ECONOMIC RESEARCH

1050 Massachusetts Avenue

Cambridge, MA 02138

May 2011

The views expressed herein are those of the authors and do not necessarily reflect the views of the National Bureau of Economic Research.

NBER working papers are circulated for discussion and comment purposes. They have not been peerreviewed or been subject to the review by the NBER Board of Directors that accompanies official NBER publications.

(C) 2011 by Klaas de Vos, Arie Kapteyn, and Adriaan Kalwij. All rights reserved. Short sections of text, not to exceed two paragraphs, may be quoted without explicit permission provided that full credit, including $(\odot$ notice, is given to the source. 
Disability Insurance and Labor Market Exit Routes of Older Workers in The Netherlands Klaas de Vos, Arie Kapteyn, and Adriaan Kalwij

NBER Working Paper No. 17053

May 2011

JEL No. J26

\begin{abstract}
$\underline{\text { ABSTRACT }}$
This paper presents information on labor market participation of the elderly, mortality and health, pathways to retirement and rates of participation in various earnings replacing programs in the Netherlands. It presents an overview of reforms to Disability Insurance (DI) and other income maintenance and early retirement programs over the past few decades, and examines to what extent these reforms have affected labor market exit routes of older workers. The overall picture that emerges is that DI receipt appears unrelated to the general health of the population and that over the last two decades relatively fewer older workers exit the labor market through DI. This reduction may, arguably, in part be attributed to stricter DI eligibility rules.
\end{abstract}

Klaas de Vos

CentERdata

Tilburg University

Warandelaan 2

5037 AB Tilburg THE NETHERLANDS

K.deVos@uvt.nl

Arie Kapteyn

RAND Corporation

1776 Main Street

P.O. Box 2138

Santa Monica, CA 90407-2138

arie_kapteyn@rand.org
Adriaan Kalwij

Utrecht University School of Economics

Network for Studies on Pensions, Aging and Retirement

a.s.kalwij@uu.nl 


\title{
Disability Insurance and Labor Market Exit Routes of Older Workers in The Netherlands
}

\author{
Klaas de Vos ${ }^{a}$, Arie Kapteyn ${ }^{b}$ and Adriaan Kalwij ${ }^{\text {cd }}$ \\ ${ }^{a}$ CentERdata, Tilburg University, The Netherlands \\ ${ }^{\mathrm{b}}$ RAND, Santa Monica, United States \\ ${ }^{\mathrm{c}}$ Utrecht University School of Economics \\ ${ }^{\mathrm{d}}$ Network for Studies on Pensions, Aging and Retirement (Netspar)
}

October 2010

\begin{abstract}
This paper presents information on labor market participation of the elderly, mortality and health, pathways to retirement and rates of participation in various earnings replacing programs in the Netherlands. It presents an overview of reforms to Disability Insurance (DI) and other income maintenance and early retirement programs over the past few decades, and examines to what extent these reforms have affected labor market exit routes of older workers. The overall picture that emerges is that DI receipt appears unrelated to the general health of the population and that over the last two decades relatively fewer older workers exit the labor market through DI. This reduction may, arguably, in part be attributed to stricter DI eligibility rules.
\end{abstract}

\section{Introduction}

Earlier research suggests that the low participation rate of persons well below the statutory retirement age of 65 in the Netherlands can, at least in part, be attributed to generous incentives to retire (cf. Kapteyn and de Vos, 1999). Until recently, the incentive to retire early was particularly strong if the employer offered an Early Retirement (ER) scheme, but an alternative route to retire via Disability Insurance (DI) was also quite attractive. A less attractive route to retire for workers is via Unemployment Insurance (UI) or Social Assistance (SA). The attractiveness of DI and its relatively easy access for elderly workers can be seen as significant contributing factors for the high prevalence of DI receipt in the Netherlands, as compared to most other developed countries. There is a large body of research showing that a considerable part of the DI recipients in the Netherlands are not really (totally) unfit to work (cf. Aarts en de Jong, 1992). De Gier et al. (2002) conclude however that most of the results of this research have hardly affected DI policy making.

In this paper we aim to contribute to the knowledge on the relationship between DI and retirement by focusing on two questions. The first question is whether, next to or instead of the strong incentives to retire via DI, we can find indications that trends in health and mortality actually played a role in the increase of the numbers of DI recipients until the early 1990s and their decrease since then. To that end we will present various graphs relating health, mortality, DI receipt and labor market participation. 
The second question concerns the effect of reforms on DI and other income maintenance and early retirement programs on the number of older workers exiting the labor market and the pathways chosen to exit and effectively retire. To assess possible effects of reforms we will present graphs which show the dates of various reforms in combination with the trends in the pathways to retirement. In addition we will estimate a model in which the reforms to DI and other programs are included as explanatory variables for changes in the pathways to retirement.

The paper proceeds as follows. Section 2 contains a brief overview of DI and other programs, and a chronological overview of reforms during the past four decades. Section 3 presents graphs on health, mortality, DI and labor force participation. Section 4 presents graphs on the pathways to retirement. Because the data on pathways only cover a limited period, section 5 presents a number of additional graphs covering a longer period. Section 6 aims to quantify the effects of reforms on the pathways to retirement. Section 7 concludes.

\section{Disability Insurance and other Social Security programs and reforms}

\section{Disability Insurance (DI)}

Introduced in 1967, the Dutch Disability Insurance (WAO, Wet op de Arbeidsongeschiktheidsverzekering) aimed to insure employees against loss of earnings as a result of long-term inability to work as a result of illness or incapacity. If after having been ill for a period of one year, the employee could not resume work, he/she would be entitled to an earnings related DI benefit which could last until the employee reached the statutory retirement age of 65 .

Starting in the 1970s, the numbers of individuals on DI in the Netherlands showed a continuous increase until the 1990s. These numbers were much higher than expected when the new DI legislation was introduced and much higher than might be expected given the average health status of the population. In fact, in the mid 1970s when unemployment was rising dramatically, the route to DI was generally used by employers as a path of least resistance to shed superfluous employees. For the employee DI was both socially more acceptable and more attractive than UI, in particular because the benefit could be received until age 65 when the old age pension would kick in.

\section{DI reforms}

With the increase in the number of benefit recipients, expenditures on DI started to rise dramatically, and since the start of the 1980s government policy has sought to reverse the trend of the ever increasing DI expenditures by various reforms to limit access to DI, increase the number of persons exiting DI and lower the average DI benefit (see table 1).

In 1985, the replacement rate of DI was lowered from 80 to $70 \%$, in the wake of the recession of the early 1980s. This affected both new entrants to DI and 'existing cases'. In 1987, access to the full DI was limited for partially disabled unemployed new entrants. In the early 1990s again government saw the need to do something about the high numbers of DI recipients and this resulted in a series of measures: the duration of the full DI benefit was limited for new entrants younger than 50, stricter disability criteria were introduced for entry into DI and younger DI recipients were to be retested. For individuals younger than 45 , the new disability 
criteria were to be used, and for persons between 45 and 50, retesting was to be done on the basis of the old disability criteria. Mainly because most employees took out a private insurance to compensate for the shorter duration of the full DI benefit for younger persons, DI remained an attractive option. Next to limiting the access and the generosity of the benefit, policies were also introduced to shift the costs to firms with high numbers of employees exiting to DI. First, the costs of sickness benefits were charged directly to the employer for two to six weeks (1994), and later on for a full year preceding the exit to DI. Second, in 1998 experience rating was introduced: for large firms in particular, the DI contributions were partly based on the DI record of the firm in question. A high exit rate into DI resulted in higher contributions.

Because all these reforms did not succeed in substantially reducing the numbers of DI recipients, by 2002 the feeling was that enough was enough and the time had come for a more radical approach. As from 2002, during the year of sickness preceding exit to DI, employer and employee are jointly responsible for taking sufficient action for reintegration into the workforce. Moreover, this sickness period can be extended if insufficient reintegration measures have been taken. As from 2004, exit to DI only happens after two years of sickness, during which time the employer pays sickness benefits. As from 2006, the new DI law, (WIA, Wet werk en inkomen naar arbeidsvermogen) makes a strict distinction between fully and permanently disabled and partially or temporarily disabled. The former receive a generous $75 \%$ of their previous earnings until age 65 (IVA, Inkomensvoorziening Volledig Arbeidsongeschikten). The latter receive a less generous benefit (WGA, regeling Werkhervatting Gedeeltelijk Arbeidsongeschikten) which depends on the previous earnings, the number of weeks worked before, and the current earnings (if any) and the percentage of previous earnings which the employee is deemed to be capable of earning. Furthermore, once again a retest operation is set up for existing DI beneficiaries younger than 50 (whose DI remains unchanged).

All in all, despite the decreased generosity of the benefit, for a long time DI remained an attractive route to exit the labor force, and whilst the levels of DI expenditures as a percentage of GDP have been decreasing considerably since the early 1980s, the number of DI recipients peaked much later, in the mid 1990s. Only the most recent series of major reforms, starting in 2002, appears to have resulted in a clear downward trend in the numbers of DI recipients.

\section{Other programs}

As mentioned above, DI benefits end when the recipient turns 65. More in general, the Dutch benefit system is characterized by a clear distinction between benefits for persons younger than 65 and benefits for persons aged 65 or above. The latter receive the flat rate state pension (SP), in most cases supplemented by an occupational pension (PP). The former may be entitled to Disability Insurance (DI), Unemployment Insurance (UI), means-tested Social Assistance (SA), or, when having retired before age 65 from a firm offering an occupational pension plan, an Early Retirement benefit (ER).

ER was introduced in most sectors during the 1970s, mainly in reaction to rising unemployment (cf. Kapteyn et al. 2010), and at least until the end of the 1990s in most cases consisted of an offer too good to refuse. In particular, workers retiring later than the earliest possible ER date were not compensated by higher benefits or lower taxes, so that in fact they faced an implicit tax rate of more than 100\% (cf. Kapteyn and De Vos, 1999). 
For workers approaching 60 who were not entitled to ER (e.g. because of an insufficiently long employment history or because they worked in a firm which did not offer ER) and who could not plausibly be retired via DI, Unemployment Insurance (UI) offered a third pathway to retirement before the statutory retirement age of 65 . In most cases, it offered a replacement rate of $70 \%$, and furthermore, until recently, no obligation to search for employment after the age of 57.5.

Upon reaching the age of 65 , all residents are entitled to the flat rate state pension (AOW) which is financed by a pay as you go social insurance contribution. Moreover, most employees accumulate fully funded occupational pension rights and supplement their state pension to (ideally) $70 \%$ of previous earnings.

Notably, traditionally in the Netherlands substantial numbers of women used to leave the labor market (long) before age 65 without an earnings replacing benefit. In recent decades, labor market participation of older women has increased rapidly, and this pathway to retirement has become less common.

\section{Reforms to other programs}

The prospect of exploding costs once the large baby boom cohorts start to reach the ER age turned out to be sufficiently threatening for effective reforms to be put in place by the end of the 1990s. In most cases a cost reduction as a result of reducing the effective ER entitlement was combined with the introduction of a more or less actuarially fair system. As a result the employee could still opt for retiring early, but with a reduced pension, or later, but with an increased pension. By 2006, the government dealt a final blow to the old ER systems by effectively terminating the tax exemption for ER contributions that would enable a retirement age lower than 65 . Only systems offering a replacement rate of at most $70 \%$ at the pension age of 65 , and actuarially fair reductions when an earlier pension age is chosen can still collect tax exempt contributions. This reform does not affect workers who are already close to 65 and have accumulated more generous entitlements.

The Dutch Unemployment Insurance (UI) system saw a major reform in 1987, affecting both eligibility and benefit period. However, since 1984, workers aged 57.5 or older could receive UI until the state pension age of 65 and this did not change in 1987. As of 2004, persons aged 57.5 or older receiving UI are no longer exempt from the requirement to seek work. In other words, they are no longer 'automatically' receiving UI until age 65 but have to try to find work and, in theory, accept a job offer. Moreover, as of October 1, 2006, the maximum duration of UI is 38 months. After that period all that is left is a means tested entitlement to Social Assistance (SA) with a benefit equal to the net minimum wage.

By and large, since 1974, for most single individuals and couples older than 65 , changes in the flat rate state pension are indexed by changes in the after tax minimum wage. Revisions include the introduction of an independent pension entitlement for married women in 1985, and the entitlement of supplementary state pension for persons with a spouse younger than 65 (1987, revised 1994). A proposed legislation to increase the statutory pension age by two years (to 67) by 2025 is still in discussion.

In addition to the universal right of a state pension from the age of 65 onwards, an increasing number of persons reaching the age of 65 (approximately $96 \%$ of men and 67\% of women in 2007. See Knoef, Alessie, and Kalwij, 2010) have been accumulating supplementary defined benefit occupational pension rights (PP). However, since the early 2000s, the generosity of 
these occupational pensions has gradually been reduced, because most of the pension funds have shifted from calculating the pension on the basis of final earnings to calculations based on average earnings. Moreover, in general the indexation of the benefits, which used to be based on the wage index, has become less generous following the successive crises on the stock market, affecting the investments of pension funds. Recently proposed pension reforms aimed at ensuring a sustainable Dutch pension system are still in discussion (cf. Stichting van de Arbeid, 2010).

$<$ Table 1 about here $>$

\section{Historical data : Mortality, health measures, Labor Force Participation (LFP) and Disability Insurance (DI)}

In this section we address the first question formulated in the introduction on whether we can find indications that trends in health actually played a role in the increase of the numbers of DI recipients until the early 1990s and their decrease since then. For this purpose we present statistics on labor force participation, the use of DI, self-reported health and mortality rates of the population. These statistics point to the conclusion that there is not much of a relationship between the numbers of persons using DI and the general health of the population.

\section{Mortality}

We present three types of figures on mortality. Figures 1 (men) and 2 (women) take the mortality rates at age 60 and 65 of 1960 as their starting point and show the ages with the same mortality rate in the period up to 2008 . For men, the age of equal mortality was actually lower than in 1960 until the early 1980s. From 1970 it shows an increase of more than 7 years up to 2008. For women, unlike for men, the age of equal mortality did not show a clear decrease in the 1960s. However, on balance, the increase up to 2008 was only marginally larger than that of men.

$<$ Figures 1 and 2 about here $>$

Consistent with the findings in figures 1 and 2, Figure 3 shows that both sexes saw their twoyear mortality rates decline between 1960 and 2007, especially at higher ages. The decrease of the mortality rate for older women was substantially larger than that of men.

$<$ Figure 3 about here $>$

Figures 4 and 5 show the time paths of mortality rates for men and women ages 55, 60 and 65 respectively. They confirm that for men, mortality in 1980 was about equal to mortality in 1960, but it also shows a clear decrease between 1970 and 2008. Women show a more uniform decline, starting from much lower levels.

$<$ Figures 4 and 5 about here $>$

Mortality and Health 
None of the figures on mortality would lead one to suspect that starting in the 1970s, the Netherlands saw an unprecedented increase in the numbers of disability benefit recipients, and that in fact, until recently, the Netherlands had one of the highest levels of DI receipt in the world. Conceivably, however, the introduction of a generous DI system may have contributed to the marked fall in male mortality during this period. Apart from mortality, not many health statistics can be found that can be used to track health over time. One of the few health statistics that is more or less comparable over a fairly long period of time is the series of self-reported good health collected by the OECD, available from 1983 until 2008. For both men and women aged 45-64, this statistic shows a somewhat erratic pattern (figures 6 and 7). For men we observe on balance an increase in the percentage reporting good health or better between 1983 and 1995 and, with a few exceptions, a fairly stable rate (of about 75\%) since then. For women, there is even less of a trend and in most years, the percentage of women reporting a good health or better hovers around $70 \%$.

$<$ Figure 6 and 7 about here $>$

\section{LFP and DI vs. Mortality}

It appears from figures 6 and 7 that self-reported health and mortality do not show a clear (negative) correlation. However, neither self-reported health nor mortality show a clear relation with DI prevalence or labor force participation either. As an example, we show employment and disability for men aged 60-64 in one figure with mortality at age 60 and 65 (Figure 8), from 1981 until 2007. For women we present the same information in Figure 9.

\section{$<$ Figure 8 and 9 about here $>$}

For men, the continuous decrease in the mortality rates has been accompanied by decreasing employment and increasing disability prevalence during the first part of the period and increasing employment and decreasing disability since approximately 1995. For women, decreasing mortality rates accompany more or less stable employment and somewhat increasing DI during the first half of the period and rapidly increasing employment and stable DI prevalence during the second half of the period. It is hard to interpret these patterns just based on health trends. During the first part of the period, one could argue that the increase in DI receipt has contributed to longer lives, by allowing workers an escape from jobs that are detrimental to health. During the second part of the period however we see that both mortality and DI receipt are falling, so then we would have to assume that causality has changed direction and that a healthier population (at least for the male population) has less need to apply for DI benefits. Altogether it seems more plausible that the changes in DI receipt are largely the result of the various reforms discussed before. It is to the effects of these reforms that we now turn.

\section{Pathways to retirement and program reforms}

In this section we address the second question formulated in the introduction and assess to what extent reforms in Disability Insurance and other income maintenance and early retirement programs have affected the pathways to retirement and the labor force participation of the population approaching the retirement age. Detailed data on the pathways to retirement are only available for a relatively short period (1989-2007). Therefore, we will also present some results that do not depend on the availability of pathways data (section 5). The focus of 
the present section is the information on the pathways to retirement from the Income Panel Survey, which we first briefly describe below.

\section{IPO Data}

The data are taken from the 1981, 1985, 1989-2007 Income Panel Study of the Netherlands (IPO, Inkomens Panel Onderzoek, CBS 2009) gathered by Statistics Netherlands. The IPO, a representative sample of the Dutch population, consists of an administrative panel dataset of, on average, about 95,000 individuals per year. Sampling is based on individuals' national security numbers, and the selected individuals are followed for as long as they are residing in the Netherlands on December 31 of the sample year. The dataset includes individuals living in institutions for the elderly, such as nursing homes. Individuals born in the Netherlands enter the panel for the first time in the year of their birth and immigrants to the Netherlands in the year of their arrival. An individual only exits the panel by death or emigration from the Netherlands. The IPO contains data on the demographic characteristics, income and labor market status for each member of a selected individual's household.

\section{IPO definitions of labor market states}

The IPO income data are based primarily on records from the tax office and institutions that pay out (insurance) benefits, and contain detailed information on all income components at an individual level. Based on the largest income component Statistics Netherlands assigns a labor market status to an individual. An individual can be (self-) employed, unemployed (UI, receives unemployment insurance or social assistance benefits), on disability (DI, receives disability or (long-term) sickness insurance benefits), ${ }^{1}$ early retired (ER, when receiving pension income) or nonparticipating (NP, no labor income, pension or benefits).

\section{(Self-)Employment}

We start with two figures presenting the employment rates (including self-employment) for men and women in three age groups (50-54, 55-59 and 60-64). Notably, the employment rate of older persons $(65+)$ can be assumed to be fairly negligible in the Netherlands.

\section{$<$ Figures 10 and 11 about here $>$}

Figure 10 illustrates the dramatic decline in the employment rate of older men as well as the reversal of this trend starting about 1995 . The pattern is particularly striking in the age group 60-64, where the employment rate dropped from almost $60 \%$ in 1981 to less than $25 \%$ in 1994 , and then picked up to more than $40 \%$ by 2007 . For women, on the other hand, we hardly observe decreasing employment rates. On the contrary, in the group of women aged 50-54 the employment rate has been increasing since 1985 and the older age groups followed this trend some years later. Notably, at the end of the observation period, in all three age groups the employment rate is still substantially below the figure for men.

Since there has been a more or less continuous series of Social Security reforms in the various programs since 1993 it is hard to assess whether some of the changes in employment may be attributed to particular reforms. It can be assumed that at least part of the increase in the employment rate of older men would not have been observed if the implicit incentives to

\footnotetext{
${ }^{1}$ The disability insurance scheme is referred to as WAO or WIA and the (long-term) sickness insurance scheme as ZW (see www.uwv.nl). Data limitations prevent a more refined classification. For instance, if an individual is partially disabled and the main source of income is from employment, this individual is classified as employed.
} 
enter the respective retirement programs (ER, DI, UI) would have remained as generous as they were in the early 1990s. Cohort effects underlie large parts of the increases in the employment rates for women. However, here we can also assume that the employment rate would have been lower if access to DI, ER and UI would not have been made more difficult and financially less attractive.

\section{Pathways to retirement}

Did the reforms affect the pathways to retirement? Undoubtedly, they did. However, it is difficult to distinguish the effects of reforms from other factors causing variation in the pathways. Moreover, even if the pathways remain stable, reforms may have effects on retirement (If, e.g., everyone chooses to retire one year later, the distribution across pathways may remain unchanged). Figures 12 and 13 show the pathways to retirement of men and women aged 50 to 64 between 1989 and 2006. A pathway is a particular exit route from employment between two subsequent years. For example, figure 12 shows that about $20 \%$ of the male workers aged 50-64 in 1989 who leave the labor market that year are on DI in 1990.

\section{$<$ Figures 12 and 13 about here >}

Looking at these figures, we see that the pattern is fairly stable given the many reforms to DI and other Social Security programs during this period. Nevertheless some trends can be observed. Over this period DI becomes a relatively less frequently used pathway to retirement for both men and women, in particular from the late 1990s onwards. For men, ER is the dominant route to retirement throughout the whole period. The year with the lowest share of ER (and the highest share of unemployment) is 1993, a year with low economic growth and rapidly increasing unemployment. For women, leaving the labor market without own source of replacement income ('Other') and relying on the income/pension of the spouse ${ }^{2}$ remains a popular pathway to retirement but has been overtaken by ER. This is likely due to changes in the rules of the occupation pension schemes and the increased participation in terms of hours of work. For both men and women, retirement at the statutory retirement age of 65 remains quite exceptional. Unemployment and Disability Insurance together make up 30 to $40 \%$ of the pathways to retirement of the persons retiring in any given year among men and about 20 to $25 \%$ among women.

\section{Historical data on activity, participation}

\section{Employed, unemployed, not in the labor force}

In this section we present labor force data for three age groups (40-44, 50-54 and 60-64) for men and women for the period 1981-2007, on the basis of the Income Panel Survey of Statistics Netherlands (see section 4). Figures 14 and 15 present employment rates, figures 16 and 17 unemployment rates, and figures 18 and 19 present the complement of employment and unemployment: not in the labor force.

$<$ Figures 14, 15, 16, 17, 18, 19 about here >

\footnotetext{
${ }^{2}$ In fact, recipients of a state pension (65+) are entitled to a supplement if they have a younger spouse without income.
} 
For men, we once again note the steep decline of the employment rate in the older age group (60-64), from almost $60 \%$ in 1981 to less than $25 \%$ in 1994, picking up to more than $40 \%$ in 2007. Unemployment peaked at less than $15 \%$ in this age group in the 1990 s, so for the most part the decline and subsequent increase in employment was complemented by a considerable increase in the percentage of men not in the labor force, peaking at more than $60 \%$ in 1994 and showing a clear decrease to less than $50 \%$ in 2007. The other two age groups show much less variation, with employment hovering close to $90 \%$ in the youngest age group and slightly lower in the age group 50-54.

For women, the employment rates show clear cohort effects: employment starts its spectacular increase during the 1980s in the younger age groups, followed with some delay, and at a much lower level, by the oldest age group. Unemployment, starting off at very low levels, hovers between 5 and 10\% after 1989 in all three age groups. The percentages not in the labor force again mainly reflect the trends in the employment rates, by showing the opposite pattern.

If we separate out the DI recipients from men not in the labor force (figure 20), we note that whereas the latter statistic showed a steep increase in the oldest age group between 1981 and 1994, the number of DI recipients only increased moderately (from about 20 to 23\%). On the other hand, a large part of the decrease in the number of men not in the labor force after 1994 in this age group is made up by a decrease in the number of DI recipients. For women the DI rates do not show decreasing trends: they more or less appear to reflect the increasing labor force participation rates.

$<$ Figures 20 and 21 about here $>$

\section{Historical data on DI vs. health, mortality}

Comparing mortality trends and DI receipt of men aged 40-44 (figure 22) we notice that this age group showed an increase in the number of DI recipients between 1981 and 1994, despite the slightly decreasing mortality rate. After 1994, the decreasing mortality rate could be seen as one of the contributing factors to the decrease in the number of DI recipients. For the women in this age group, mortality and DI receipt show a negative correlation (figure 23), if any.

\section{$<$ Figures 22 and 23 about here >}

In the age group 60-64, the pattern is comparable: for men (figure 24), DI and mortality show opposing trends until 1994 but both move downward afterward. For women (figure 25), DI and mortality show a negative correlation throughout the whole period. Both for this age group and for the age group 40-44, the negative correlation would be the direct result of the cohort effects in female labor force participation. Female employment rises steadily during the period and DI receipt rises with it. Since at the same time mortality decreases steadily, a negative correlation is the result.

\section{$<$ Figures 24 and 25 about here $>$}

For health, we only have a crude measure (the percentage of people with self-reported health good or better), for a broad age group (45-64). For men, there is some indication that an 
improvement of the health measure coincides with a decrease in DI receipt. For women there is no clear trend in the health measure, while DI receipt tends to increase slightly.

\section{$<$ Figures 26 and 27 about here $>$}

A final perspective is given by Figure 28 which shows the difference between DI receipt in the age groups 60-64 and 40-44, for men and women. Notably, for men this difference is much higher than for women throughout the whole period. This probably does not really mean that disability prevalence increases much faster with age among men than among women. More likely it is caused by the fact that women who left the labor market relying on the income of their spouse have no access to DI. The declining difference between men and women is indicative of the fact that more and more older women stay on the labor market. The fact that the difference between 40-44 year old men and 60-64 year old men decreases at the end of the period suggests that the earlier, larger difference between these age groups is not really the result of older people having a lower ability to work but is largely caused by the fact that it used to be easy to get access to DI for older men who wanted or were forced to leave the labor market before the statutory retirement age of 65 .

$<$ Figure 28 about here $>$

In summary, health and mortality do not seem to be strongly related to DI prevalence. At the end of the period, the reforms appear to be successful in causing a decrease in DI prevalence. In the next section we will see if this result can be confirmed by a more rigorous quantitative analysis.

\section{An explorative empirical analysis}

The empirical evidence presented in the sections above seems to suggest that DI receipt is unrelated to the general health of the population and that DI reforms may have led to relatively fewer older workers exiting the labor market through DI. In this section we empirically investigate these issues using a regression model. Such an approach makes it possible to control for cyclical variation in the labor market exit rate and to quantify the impacts of health and policy reforms on the various pathways to retirement conditional on age and gender. The policy reforms are modeled using year-dummy variables indicating reforms. The data are taken from the Income Panel Study of the Netherlands (see section 4). We select individuals who are 50-63 year of age and aggregate these data based on year, gender and age category (50-54, 55-59 and 60-63). ${ }^{3}$ Over the time period 1989-2006 we have 108 observations.

\section{Empirical framework: A simple pathway model}

Individuals can exit employment through the pathways Disability Insurance (DI), early retirement, (ER), Unemployment Insurance (UI) or non-participation (NP). With individual level data this can be modeled using a competing risk model. We use, however, aggregated data to carry out the empirical analysis. This means we do not have individual pathways to retirement but proportions of (groups of) people that choose certain pathways. We define

\footnotetext{
${ }^{3}$ We exclude 64 year old persons as most often their employment contract is automatically terminated when they reach the statutory retirement age of 65 and they start receiving a state pension.
} 
$p_{a g t}^{c}$ as the proportion of employed individuals with age $a$ and gender $g$ that leave employment through pathway $c$ in year $t$. For a logit-type model for each pathway we can specify the following linear regression model:

$$
\ln \left(\frac{p_{a g t}^{c}}{1-p_{a g t}^{c}}\right)=\alpha_{0 c}+\sum_{j=1}^{k} \alpha_{c j} D_{j t}+\beta_{0 c} X_{a g}+\beta_{1 i} H_{a g t}+\beta_{2 i} \ln \left(E_{a g t}\right)+\varepsilon_{a g t}^{c},
$$

where $c \in(\mathrm{DI}, \mathrm{ER}, \mathrm{UI}, \mathrm{NP}), t \in\{1989, . ., 2006\}^{4}$, the $D_{j t}$ 's are dummy variables indicating reforms (see table 1), $X_{a g}$ are explanatory variables (gender and age), $H_{a g t}$ is remaining healthy life expectancy ${ }^{5}$ and $E_{a g t}$ is the total outflow from employment. In the estimation we use the pathway non-participation (NP) as the reference category. ${ }^{6}$ The error term $\varepsilon_{a g t}^{c}$ is heteroskedastic and this is taken into account when calculating the standard errors. For details on the estimation we refer to Cameron and Trivedi (2005). We use an Instrumental Variables estimator to take into account that the total outflow from employment $E_{\text {agt }}$ may, for instance, be influenced by unobserved variables also affecting a specific pathway. ${ }^{7}$ The additional instrument is total employment by age, gender and year obtained from OECD statistics. The justification for choosing this additional instrument is that the outflow from employment will be positively related with total employment since the more people are employed the more people are at risk of leaving employment, while we do not expect total employment to affect the different pathways once we control for total outflow from employment. ${ }^{8}$

\section{Empirical results}

The first column of Table 2 presents the estimation results of a linear regression model explaining the (logarithm of) total flow from employment. The remaining columns present estimation results for the model discussed above for each of the pathways. The total outflow from employment increases with age and is higher among women than men. The total outflow appears unrelated to health. The DI reform in 1996 and the reforms in 2006 are significantly and negatively associated with the outflow from employment but there is no significant association between the other reforms and the outflow from employment.

Conditional on the total flow from employment and compared to male workers, female workers are less likely to exit employment through DI, ER and UI and more likely to exit employment without own source of replacement income. With age ER becomes relatively more important and DI and UI become less important exit routes. In line with our conclusions drawn from the various figures in the sections above, we find no significant relationship between healthy life expectancy and the pathways to retirement. The 1993 and 2002 DI reforms are associated with a lower exit probability into DI whilst the 1998 reform (the

\footnotetext{
${ }^{4}$ Outflow is from $t->t+1$. We do not observe the outflow in 1981 and 1985 because the subsequent years are not in our data. Hence 1989 is our first year and 2006 is the last year in our "flow" sample.

${ }^{5}$ Remaining healthy life expectancy is defined as the number of years a person of certain age and in a particular year is expected to live in good health where good health is defined as absence of chronic disease, absence of physical limitations, or perceived good health.

${ }^{6}$ We use the normalization: $p_{a g t}^{\mathrm{NP}}=1-p_{a g t}^{\mathrm{DI}}-p_{\text {agt }}^{\mathrm{ER}}-p_{\text {agt }}^{\mathrm{UI}}$.

${ }^{7}$ Another possible bias may come from measurement error in IPO data. For this reason we use an instrument based on OECD data.

${ }^{8}$ We follow Bound, Jaeger and Baker (1995) and present a test for whether or not the instrument has sufficient explanatory power (see table 2).
} 
introduction of experience rating) appears to have affected the exit probability to DI positively. We have no explanation for this latter finding but the termination of experience rating in 2008 hints towards this indeed being an ineffective instrument for reducing DI inflow. A counterintuitive finding is the positive effect of the 2000 reform on ER and its negative impact on DI inflow. This may be the result of workers (and employers) making more use of ER in anticipation of further limitations on ER eligibility. In most cases the coefficients of the reforms on the estimated probability to exit via unemployment have the opposite sign as the ones found for the probability to exit to DI, suggesting a possible substitution between these two routes.

$<$ Table 2 about here $>$

To obtain further insights into these empirical results, Table 3 presents the predicted percentage-changes in the total outflow and the pathway probabilities due to a change in the explanatory variables. The total outflow from employment is $36 \%$ higher among women than men (first row). The outflow from employment more than quadruples for workers age 60-63 compared to workers age 50-54 and with age workers are increasingly more likely to flow into early retirement than into disability or unemployment (rows 2 and 3). Again, health appears to have no effect on the total outflow from employment and the pathways to retirement (row 4). Total outflow from employment is not significantly associated with the outflow from employment into DI but is positively associated with the flow into ER. This suggests that when the total outflow from employment is high, for instance, as a result of a downturn in the economy, the exit route ER is relatively more frequently used.

Finally, the last row suggests that, cumulatively, the reforms have had substantial effects: they have reduced the total outflow from employment with $38 \%$ and, moreover, reduced the shares of the pathways into DI and ER with, respectively, $40 \%$ and $20 \%$, at the expense of an increase in the outflows into UI and nonparticipation ("other") with, respectively $17 \%$ and $53 \%$.

$<$ Table 3 about here $>$

\section{Conclusion}

The relatively generous and easily accessible DI benefit can be seen as an important institution contributing to the large numbers of workers retiring from the labor market at relatively early ages in the Netherlands. There are no indications that the high numbers of DI are related to high mortality rates or high percentages of persons living in bad health.

By a continuous series of reforms, the government has attempted to reverse the trend of ever expanding numbers of DI recipients. Until recently, these reforms did not result in much of a decrease in the number of DI recipients. Despite the reforms, DI remained attractive and accessible. However, it is likely that without reforms, the number of DI recipients would have kept on increasing much further. The empirical analysis shows that several reforms to the DI, ER, and UI programs are related to the pathways to retirement. Notably, these reforms are found to be associated with reductions in the labor market exit rate of older workers and the percentage inflow into DI and ER. This has, arguably, contributed to the observed increased labor force participation rate among the 55-64 population from the mid-1990s onwards. 


\section{References}

Aarts, L.J.M. and Ph.R. de Jong (1990), Economic aspects of disability behaviour, PhD-thesis Erasmus University, Rotterdam.

Bound, J., D.A. Jaeger and R.M. Baker (1995) Problems with instrumental variables estimation when the correlation between the instruments and the endogenous explanatory variable is weak, Journal of the American Statistical Association, 90, pp. 443-450

Cameron, A.C., and P.K.Trivedi. 2005. Microeconometrics, Methods and Applications. New York: Cambridge University Press

Centraal Bureau voor de Statistiek (CBS), 2009, Documentatierapport Inkomenspanel onderzoek (IPO), Centrum voor Beleidsstatistiek, Voorburg

De Gier, E., R. Henke and J. Vijgen (2003), The Dutch disability insurance act (WAO) and the role of research in policy change, Amsterdam School for Social Science Research Working Paper 03/02.

Kapteyn, A., and K. de Vos. 1999. Social Security and Retirement in the Netherlands, in: Jonathan Gruber and David A. Wise (eds.), Social Security and Retirement around the World, The University of Chicago Press, 269-304.

Kapteyn, A., K. de Vos and A. Kalwij, 2010. Early Retirement and Employment of the Young in the Netherlands, in: Jonathan Gruber and David A. Wise (eds.) Social Security Programs and Retirement around the World: The Relationship to Youth Employment, The Chicago University Press, Chapter 8, p. 243 - 259.

Knoef, M., R.J.M. Alessie, A. Kalwij (2010), "Changes in the income distribution of the Dutch elderly between 1989-2020: a dynamic microsimulation”, Netspar working paper. 
Stichting van de Arbeid, 2010, Pension Accord Spring 2010 (Pensioen Akkoord), www.stvda.nl 
Figure 1

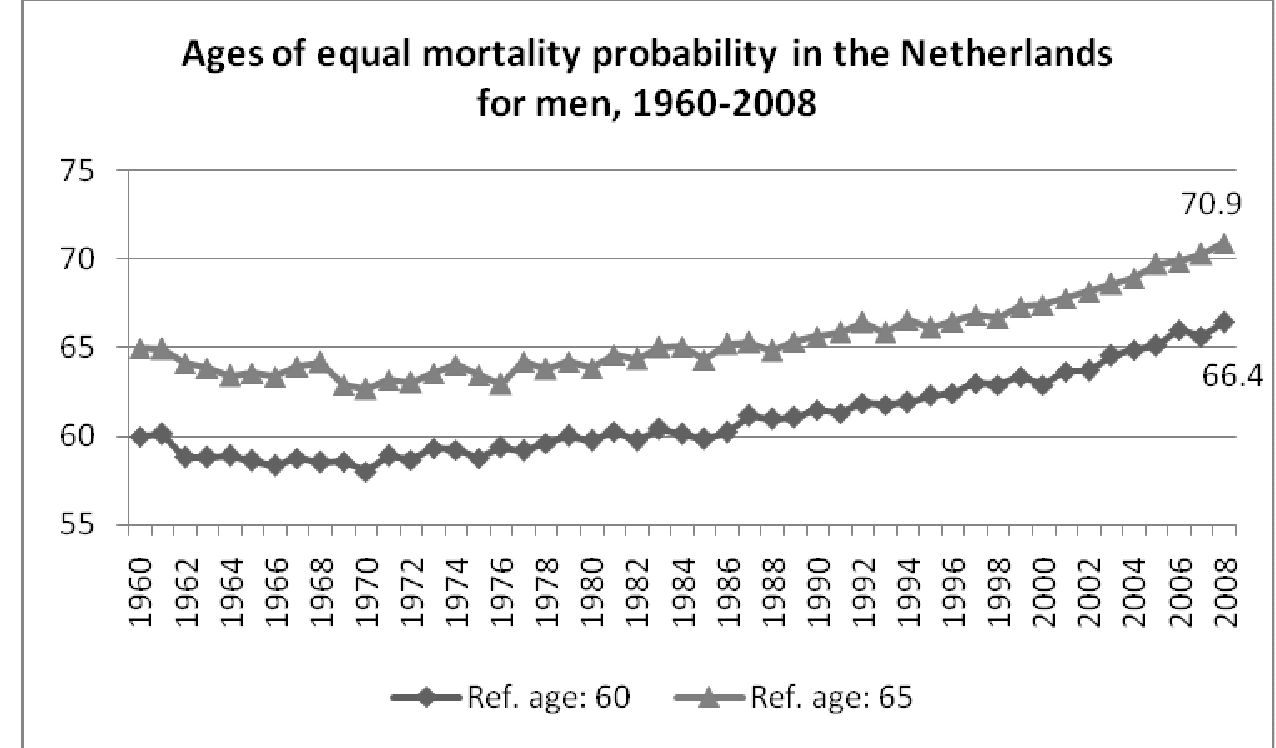

Figure 2

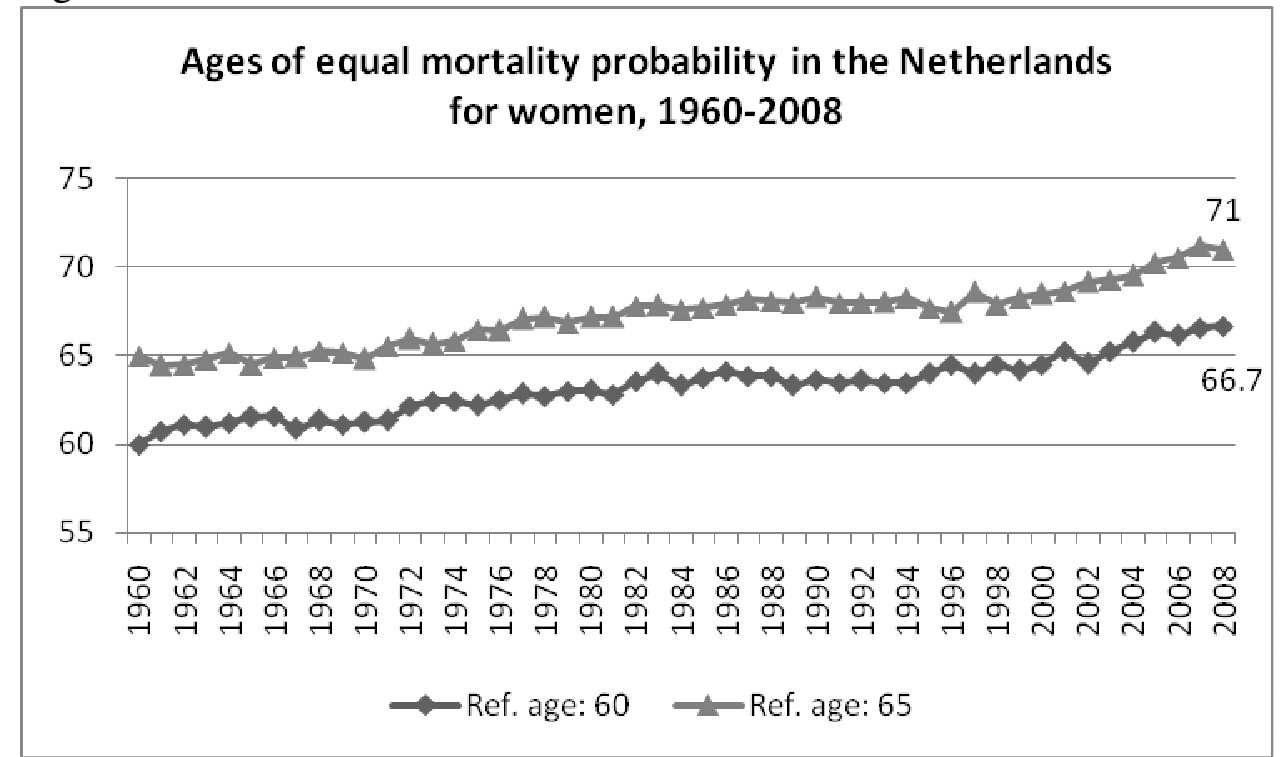


Figure 3

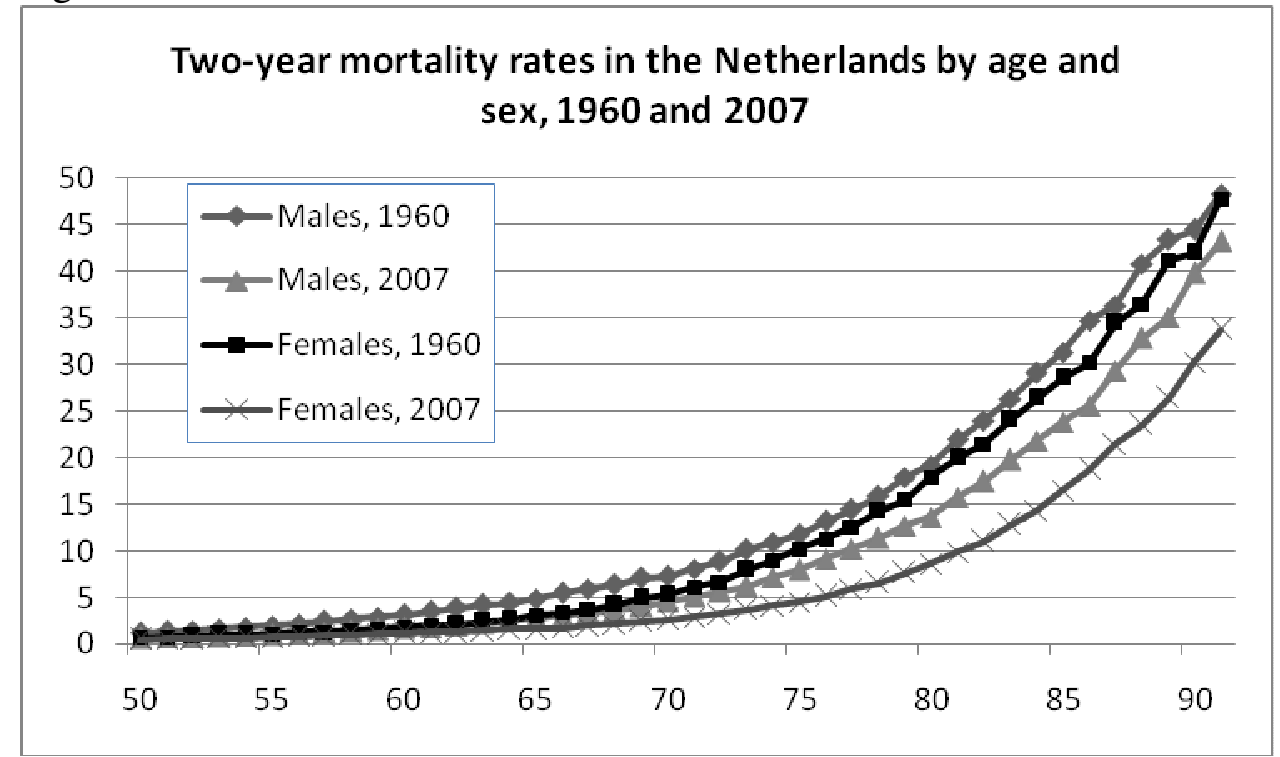


Figure 4

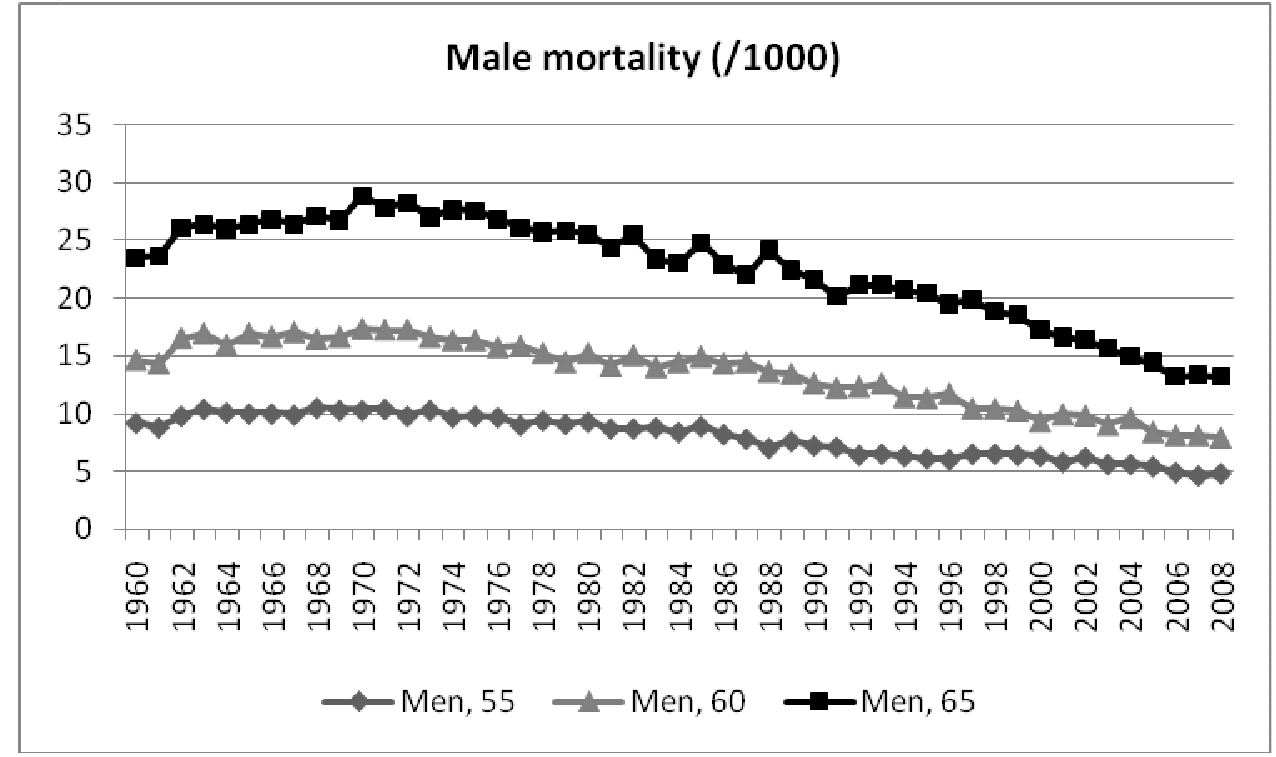

Figure 5

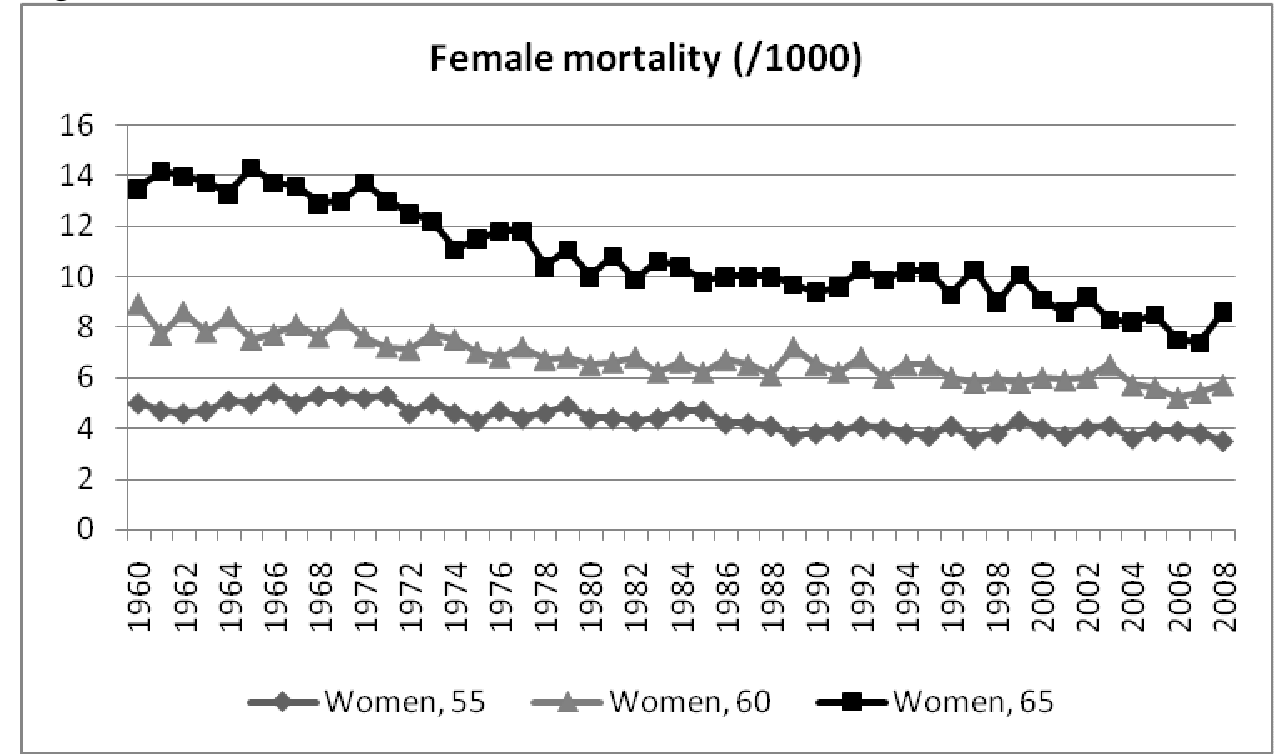


Figure 6

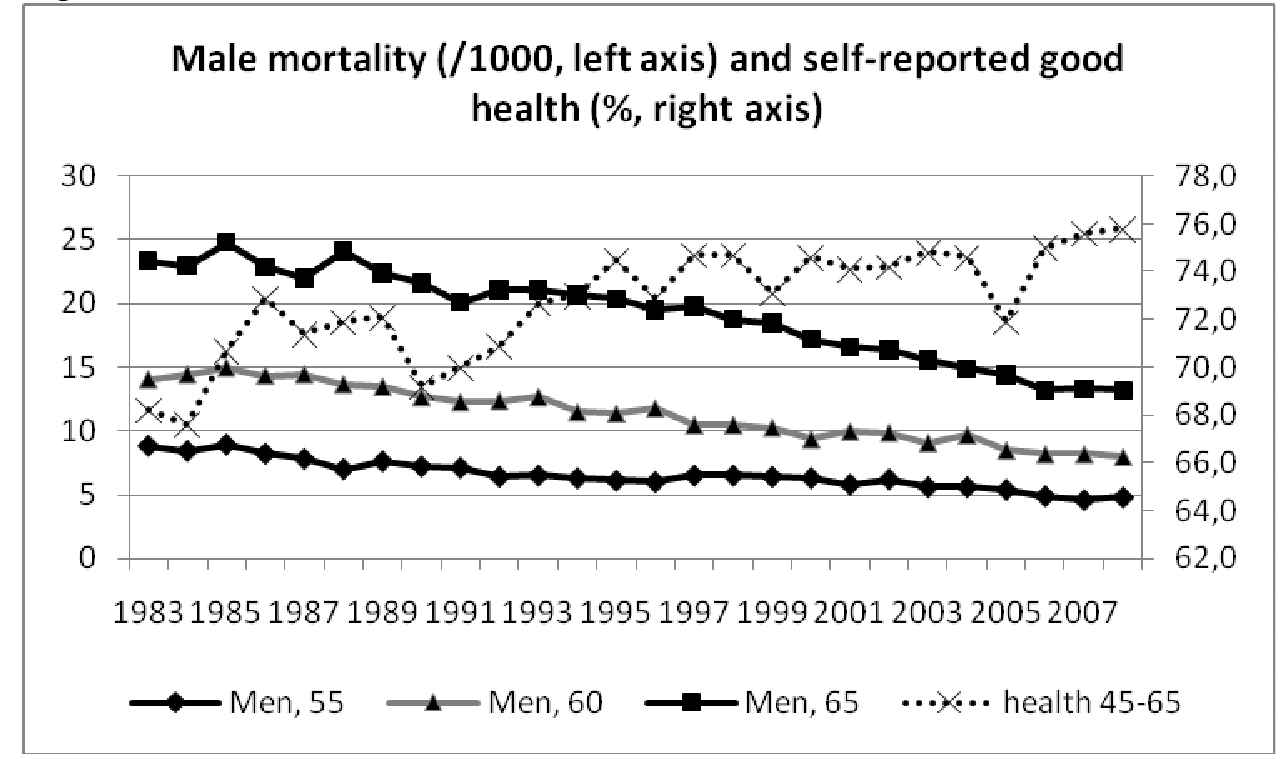

Figure 7

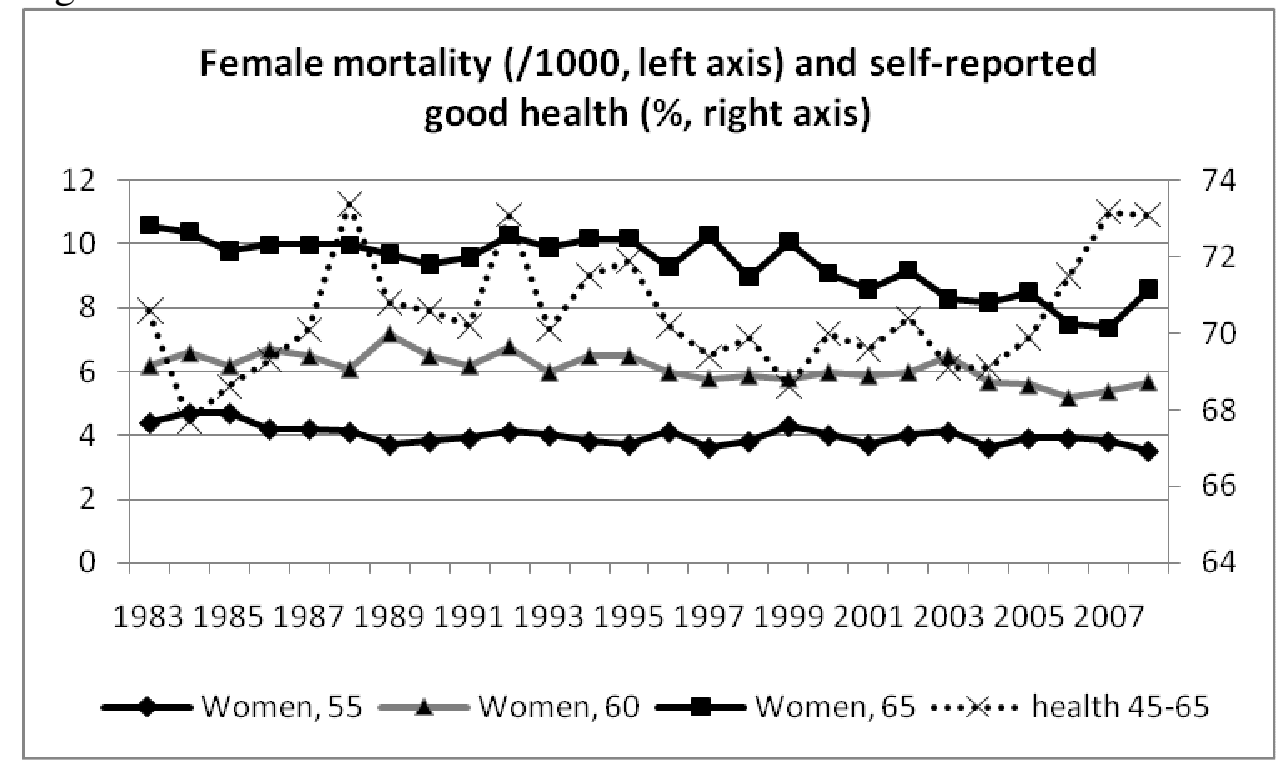


Figure 8

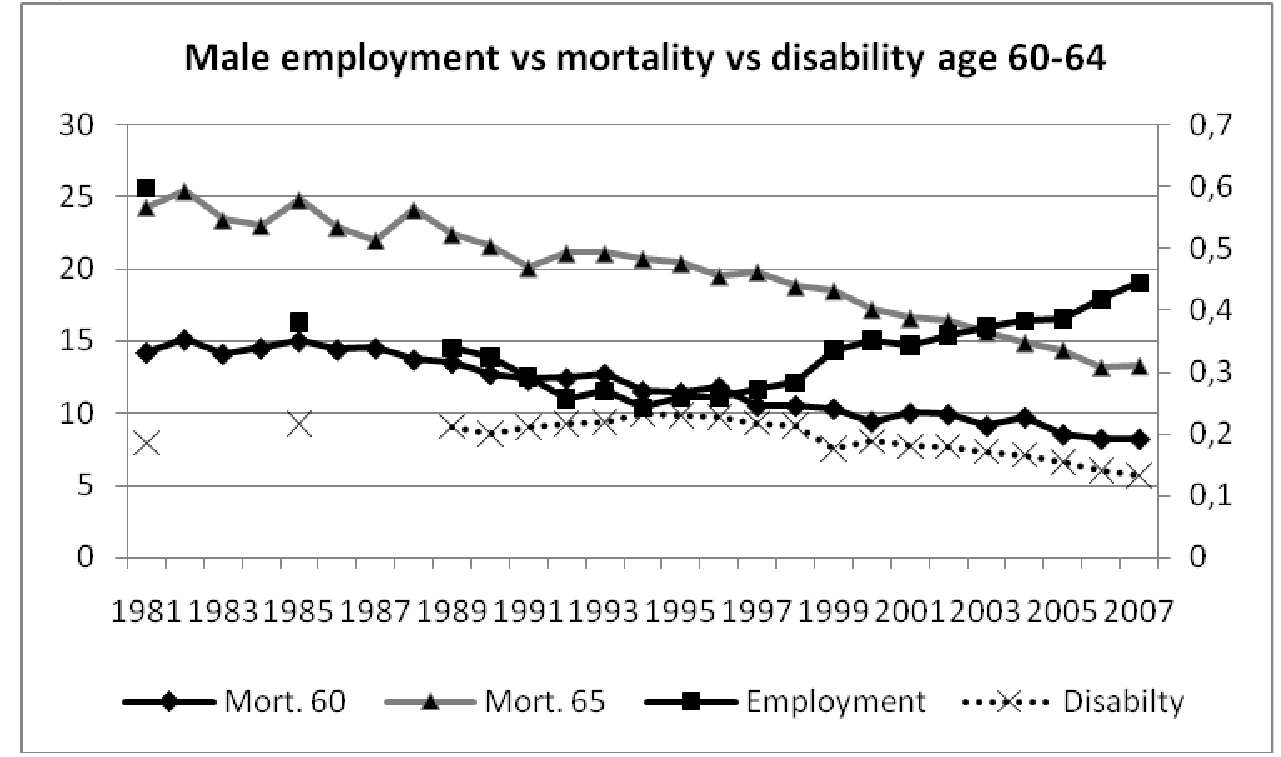

Figure 9

Female employment vs mortality vs disability age 60-64

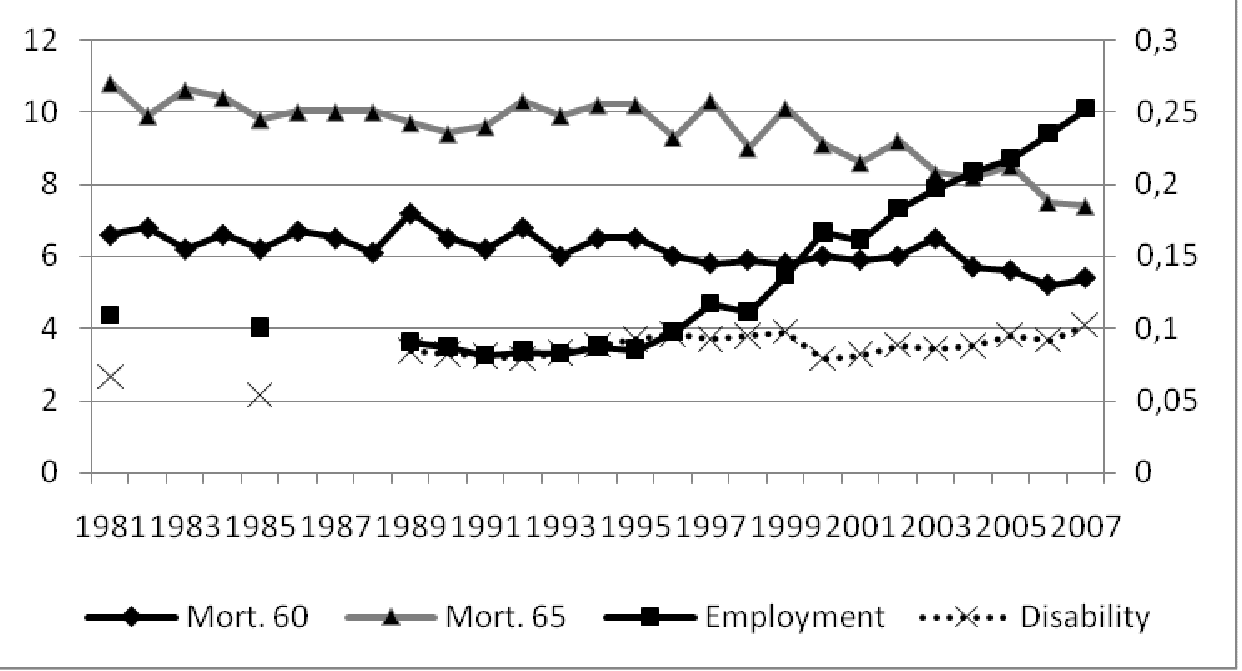


Figure 10

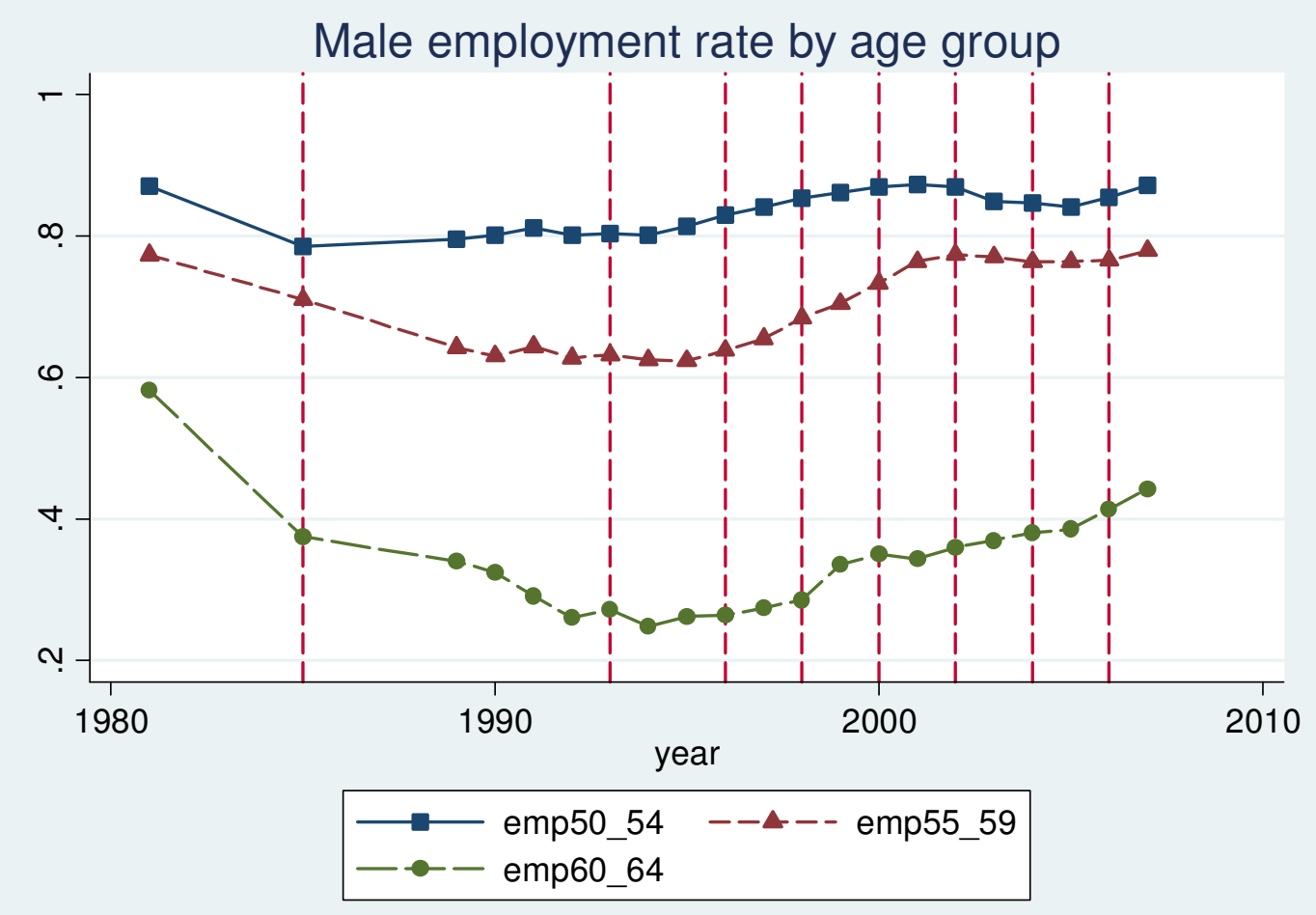

Figure 11

Female employment rate by age group

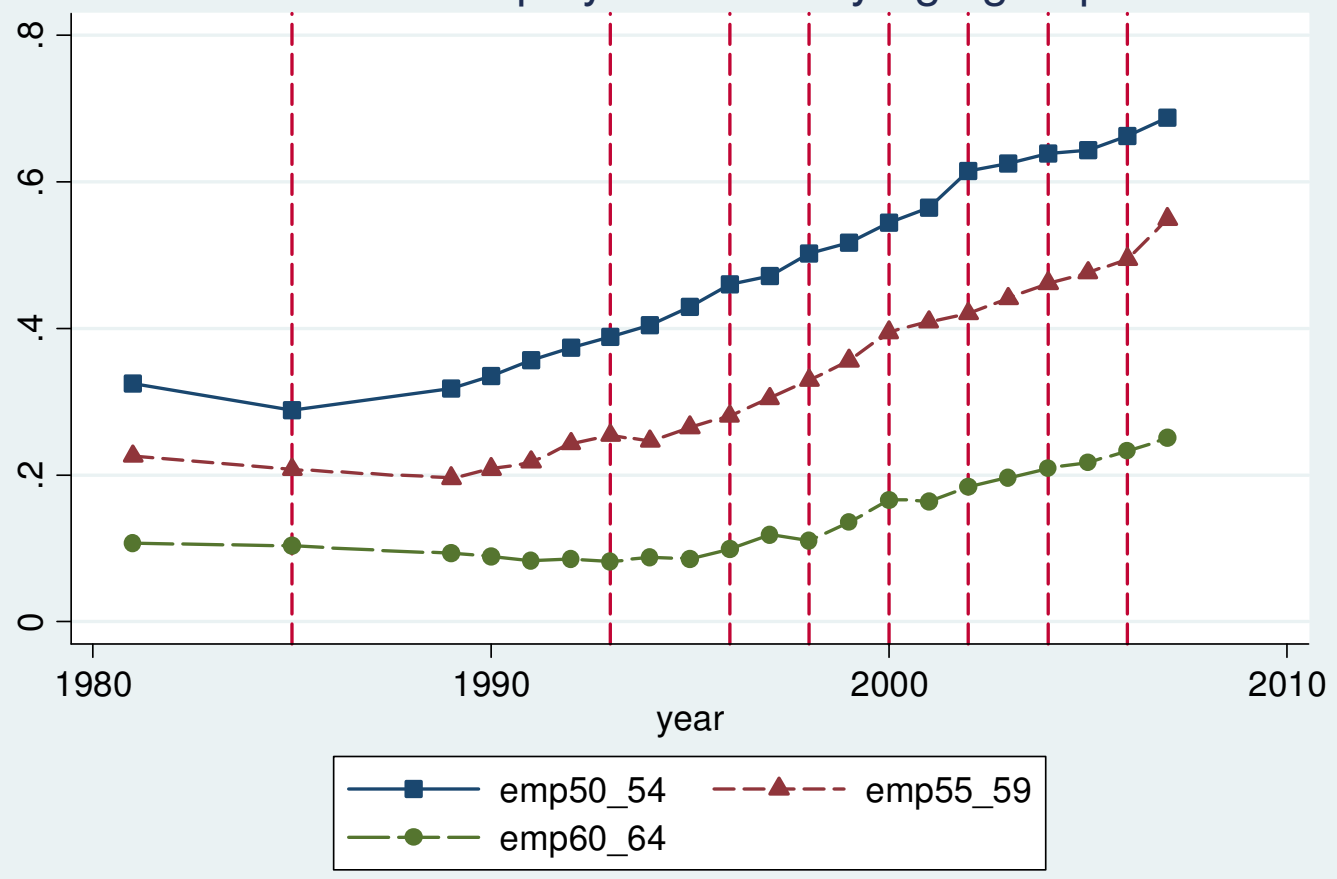


Figure 12

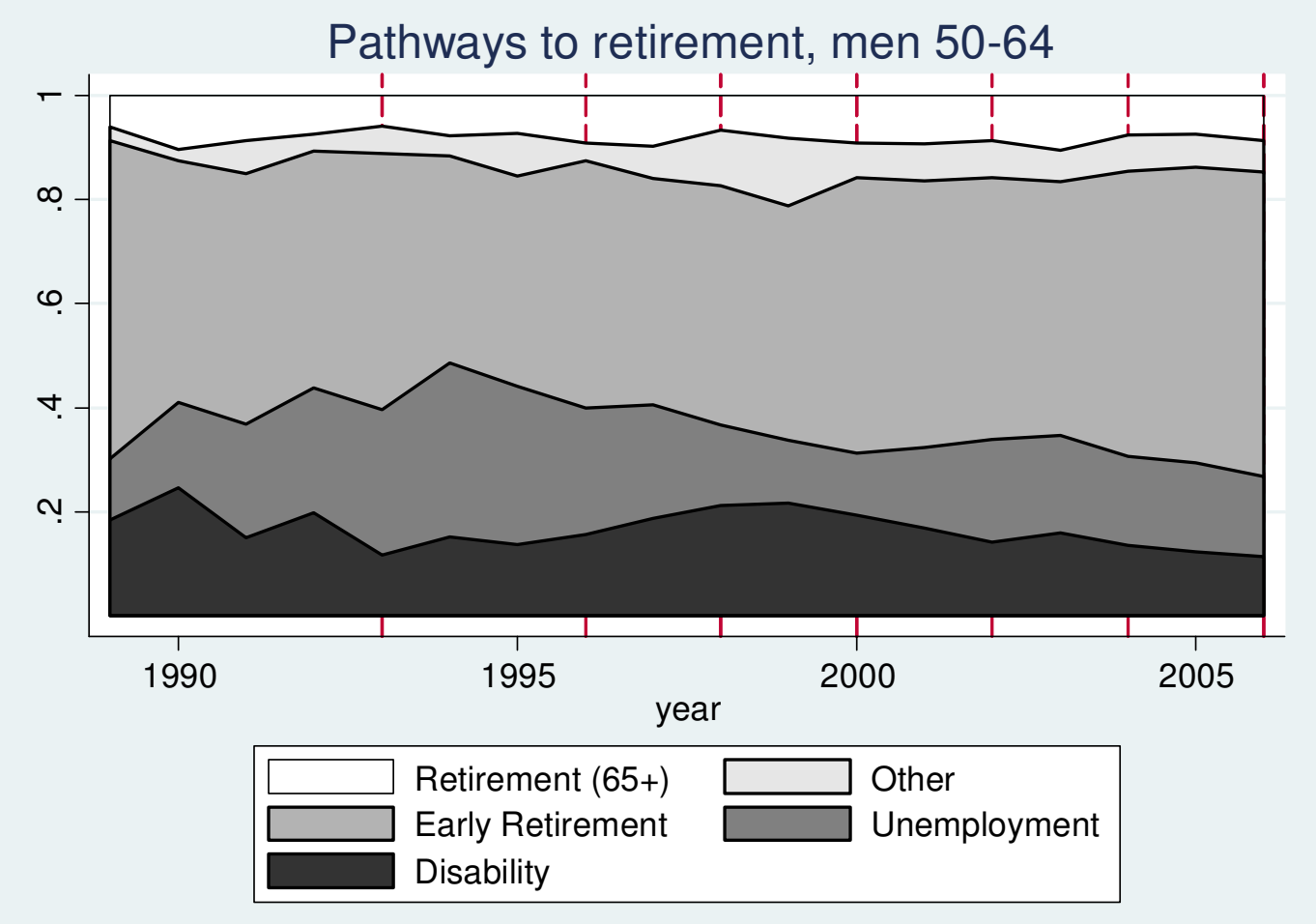

Figure 13

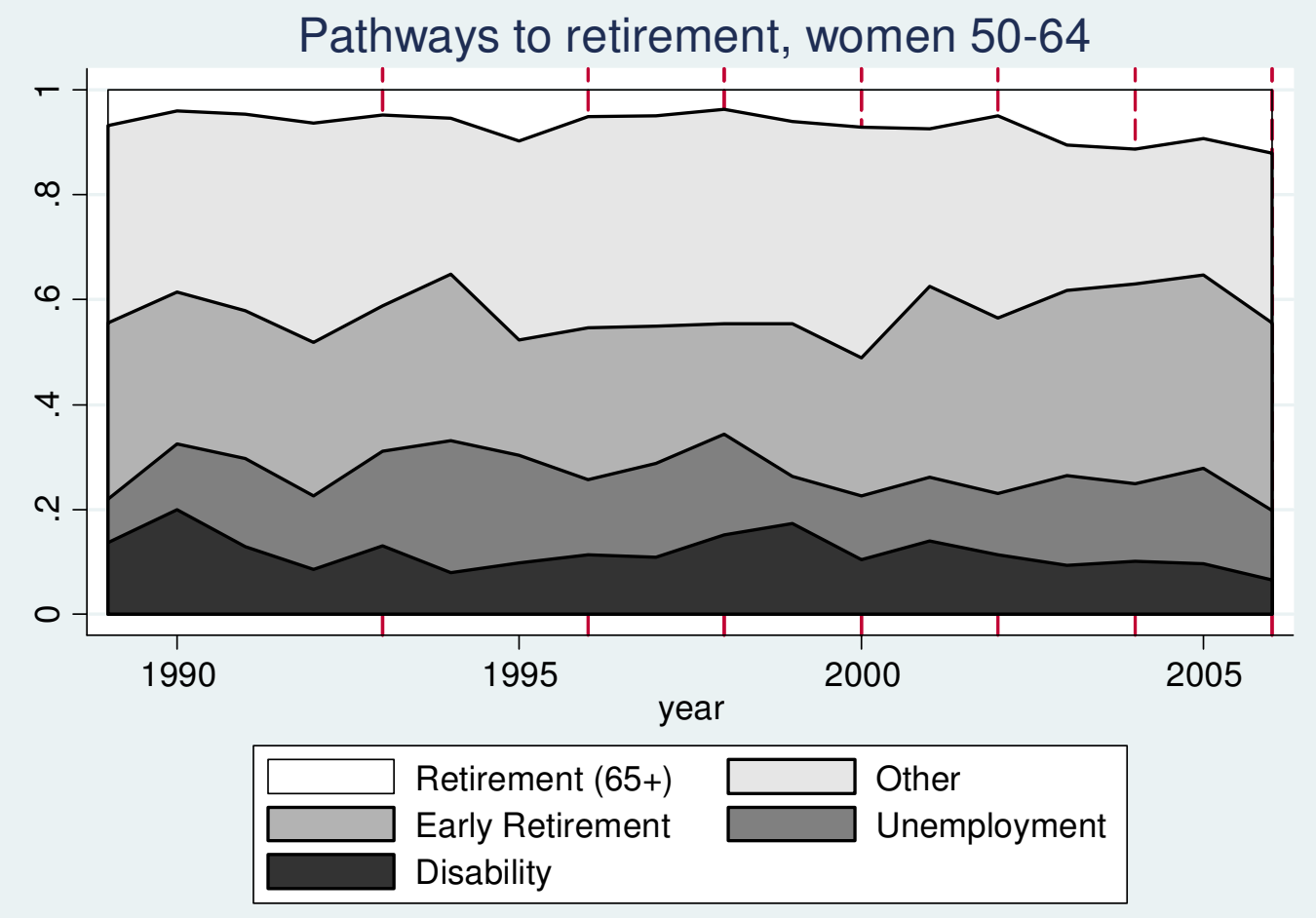


Figure 14

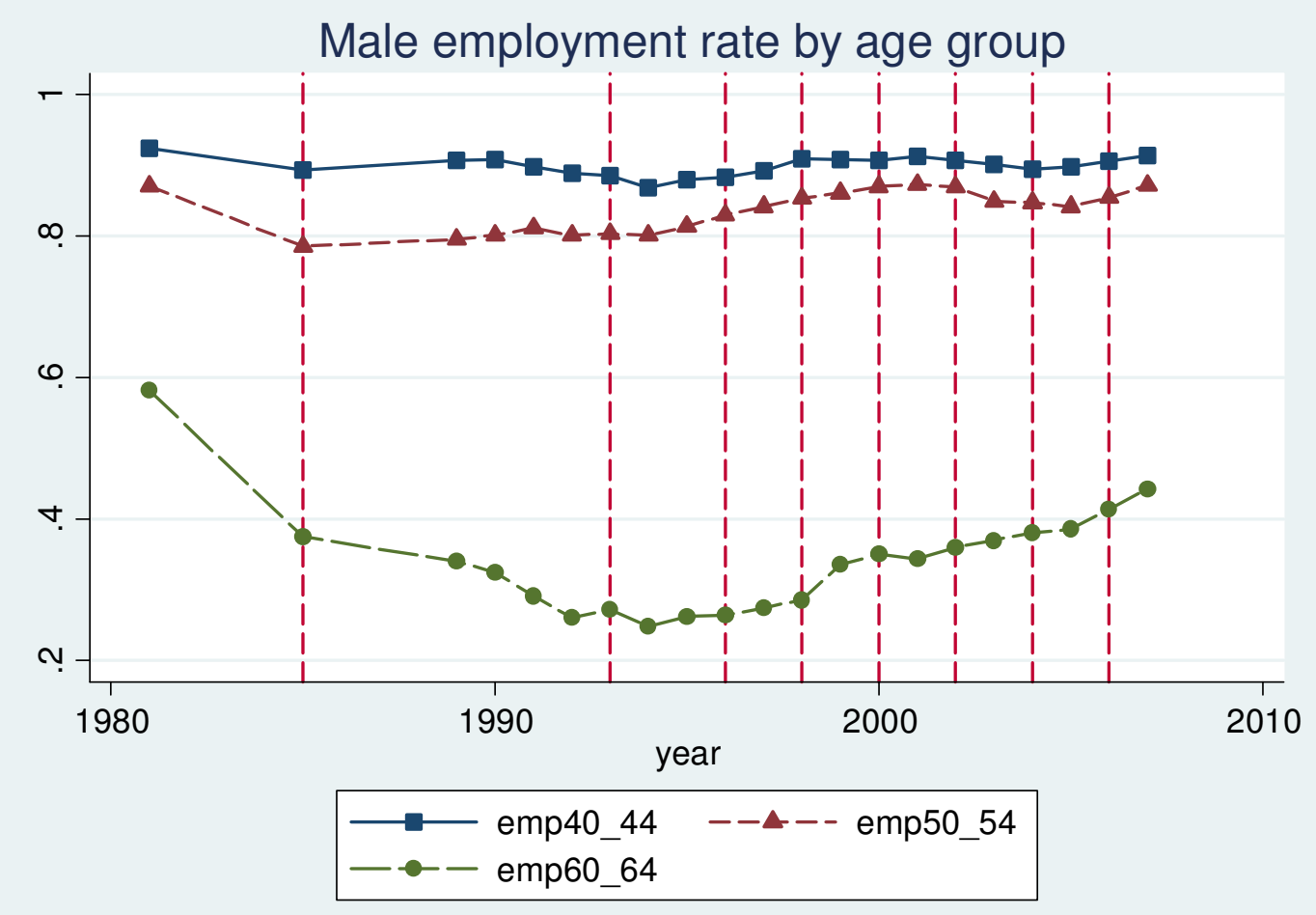

Figure 15

Female employment rate by age group

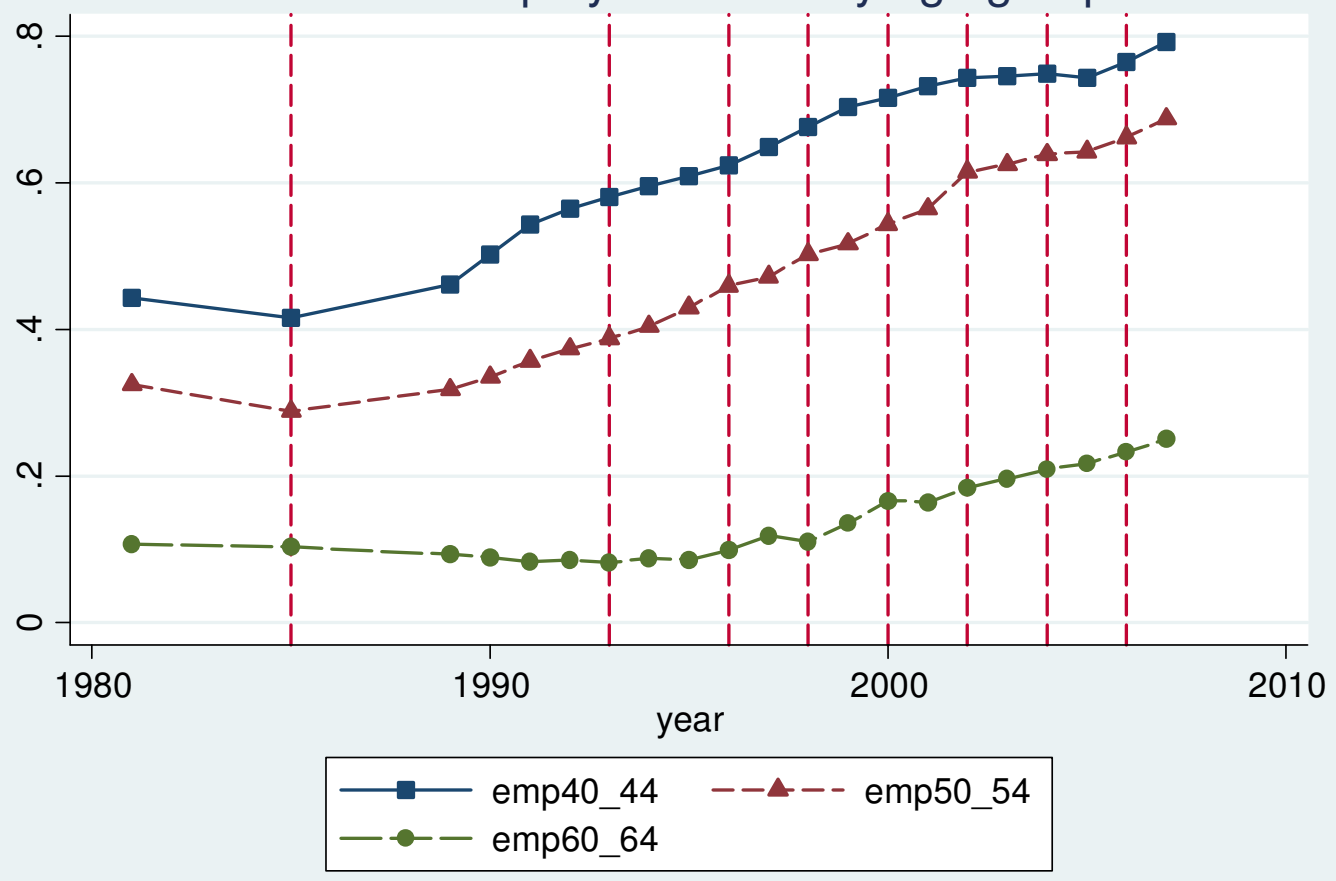


Figure 16

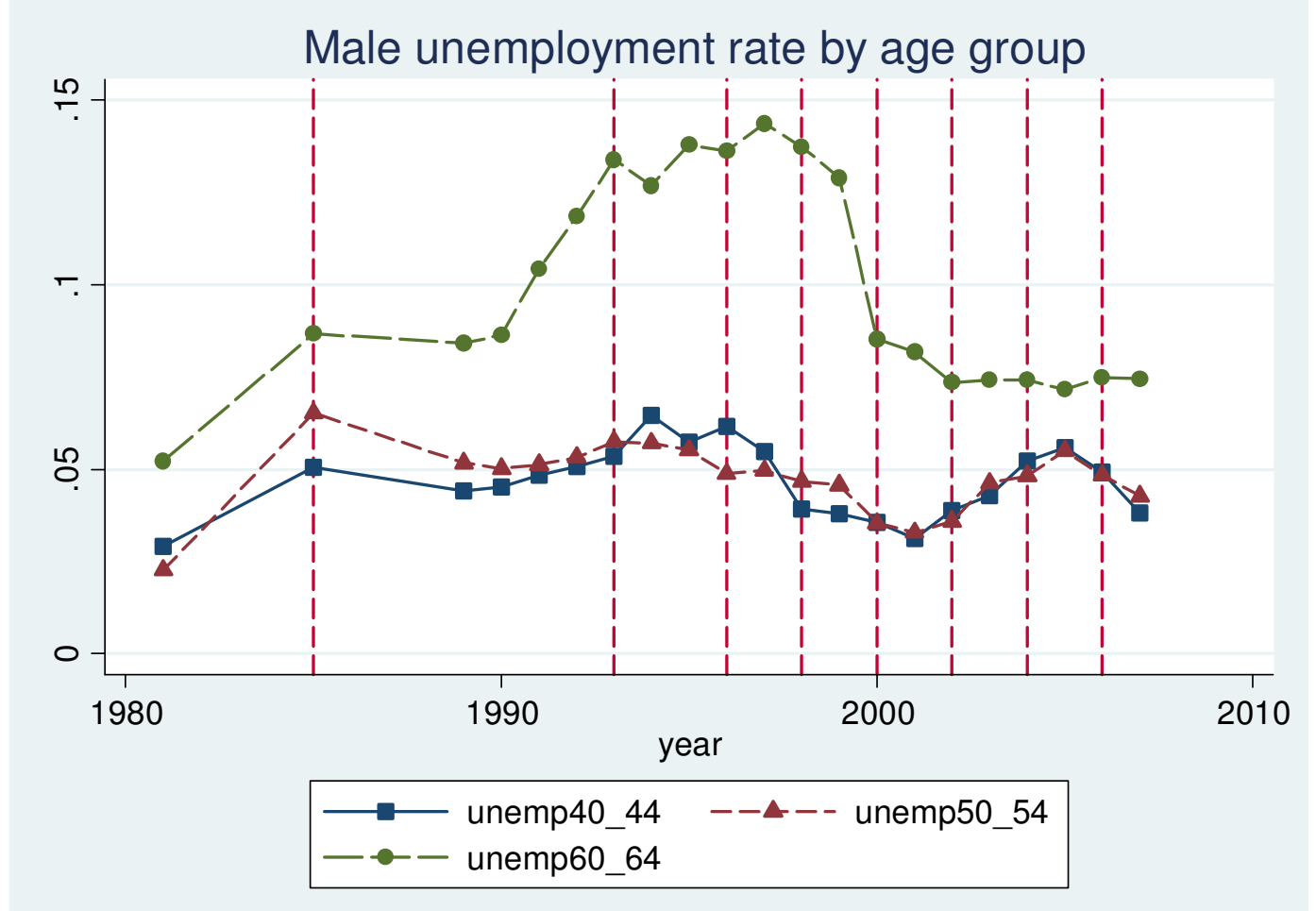

Figure 17

Female unemployment rate by age group

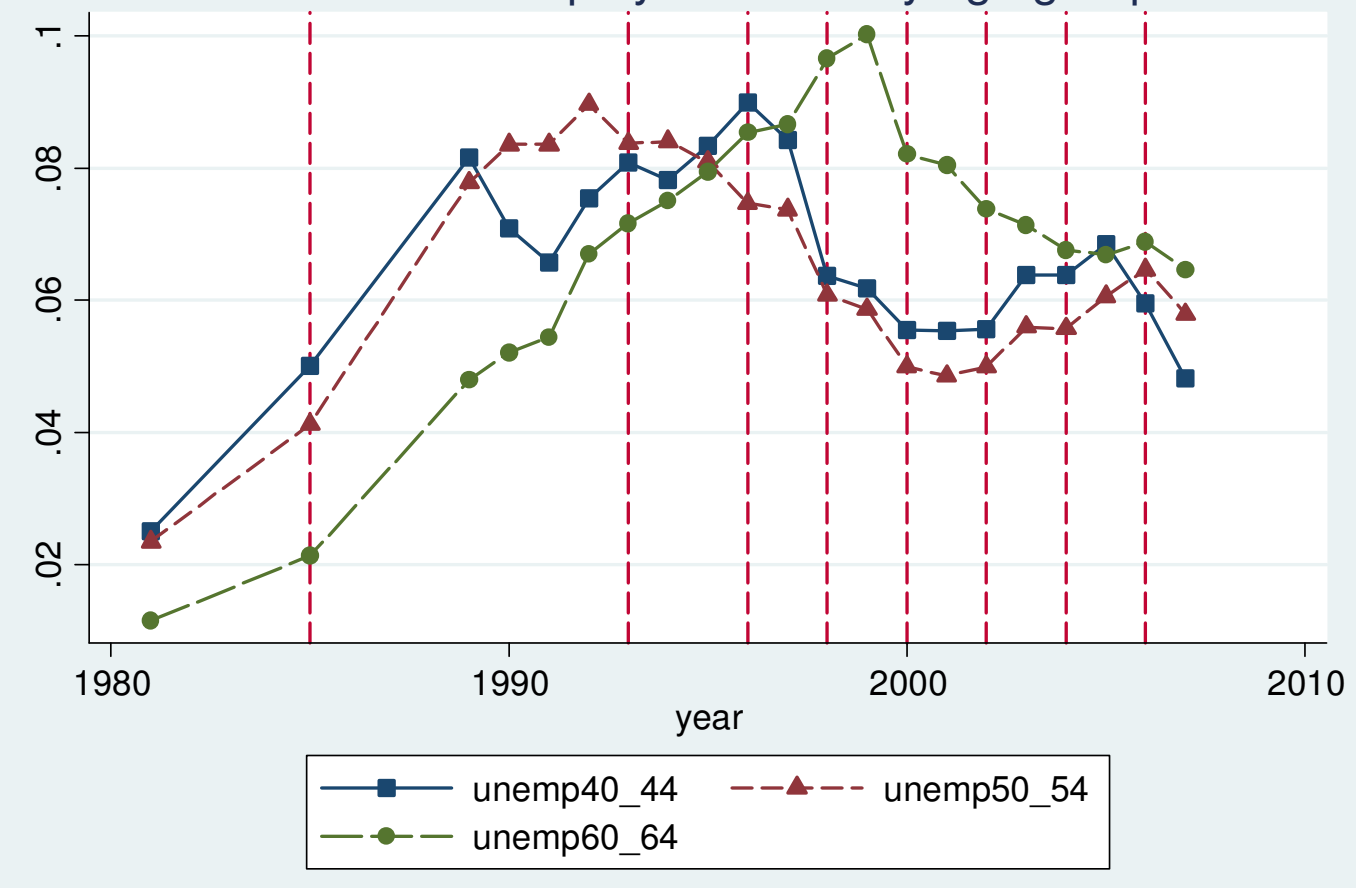


Figure 18

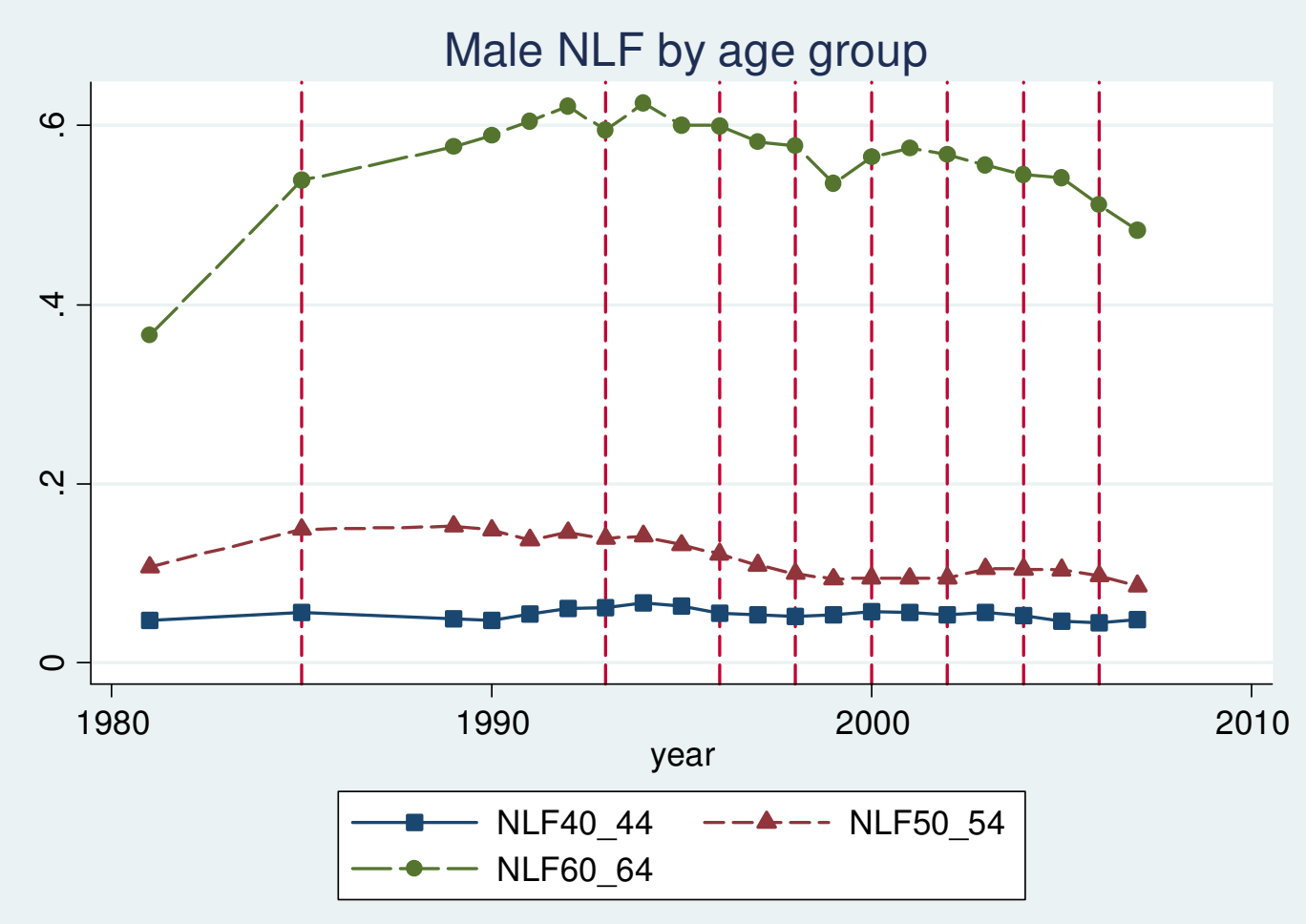

Figure 19

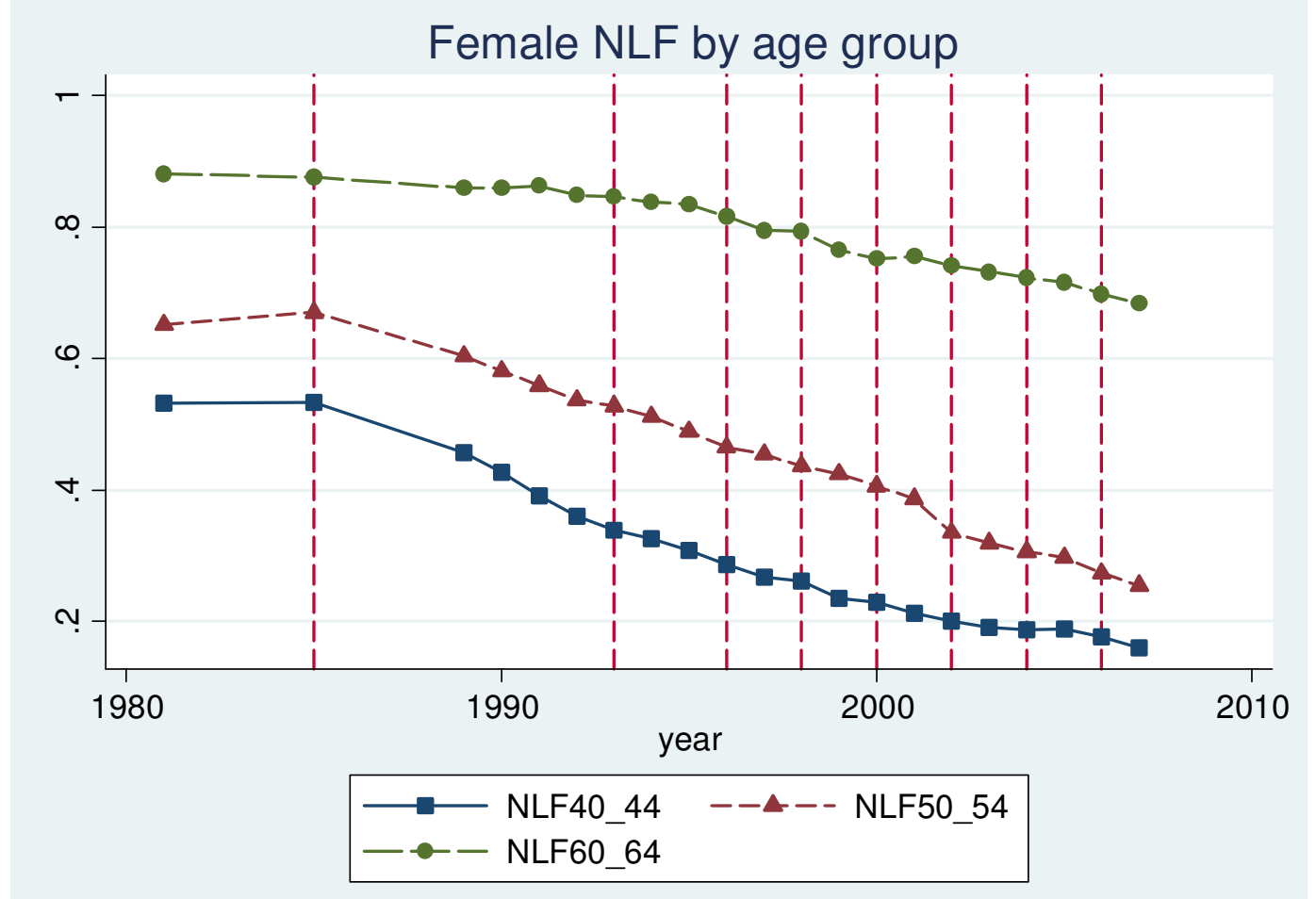


Figure 20

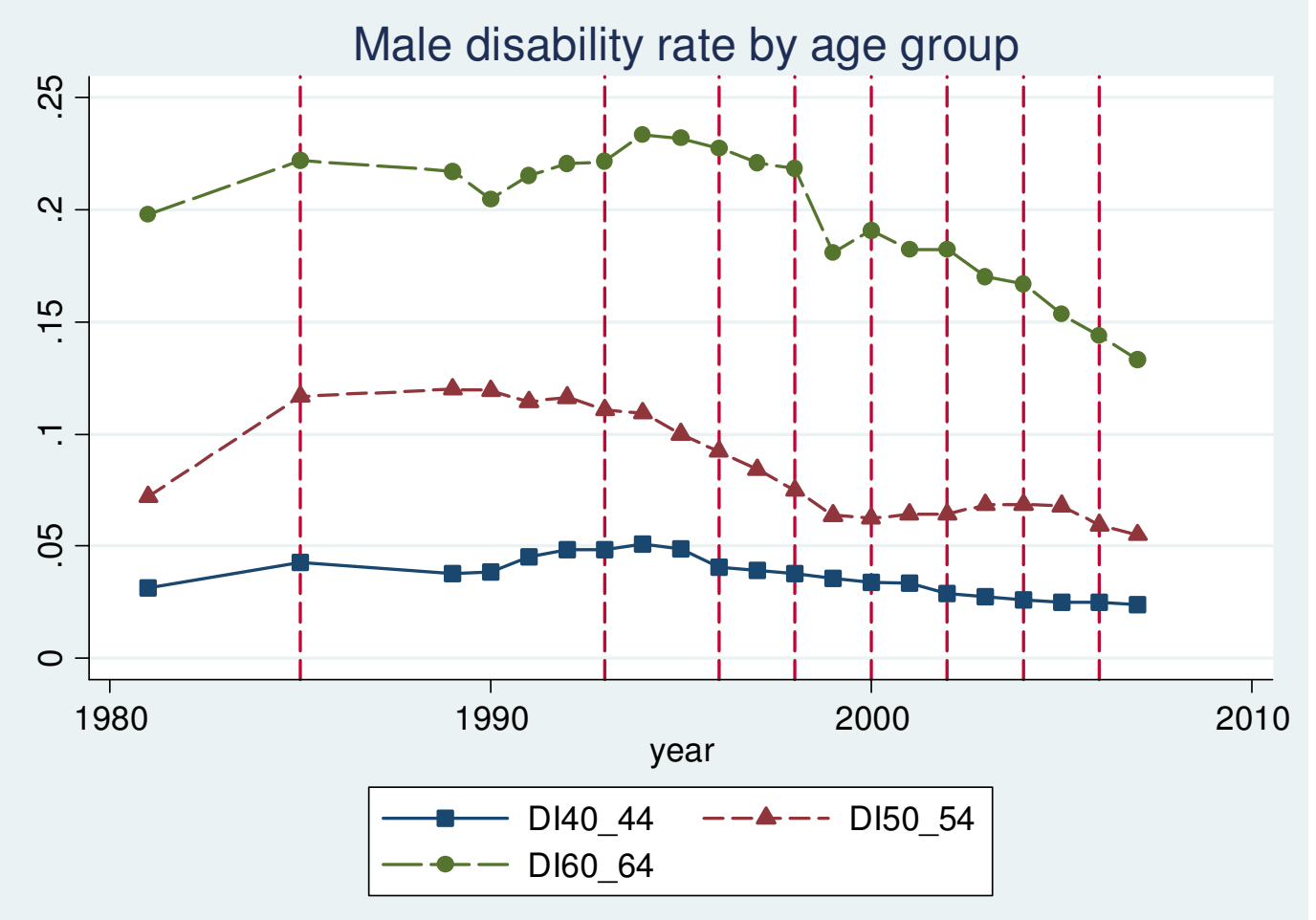

Figure 21

Female disability rate by age group

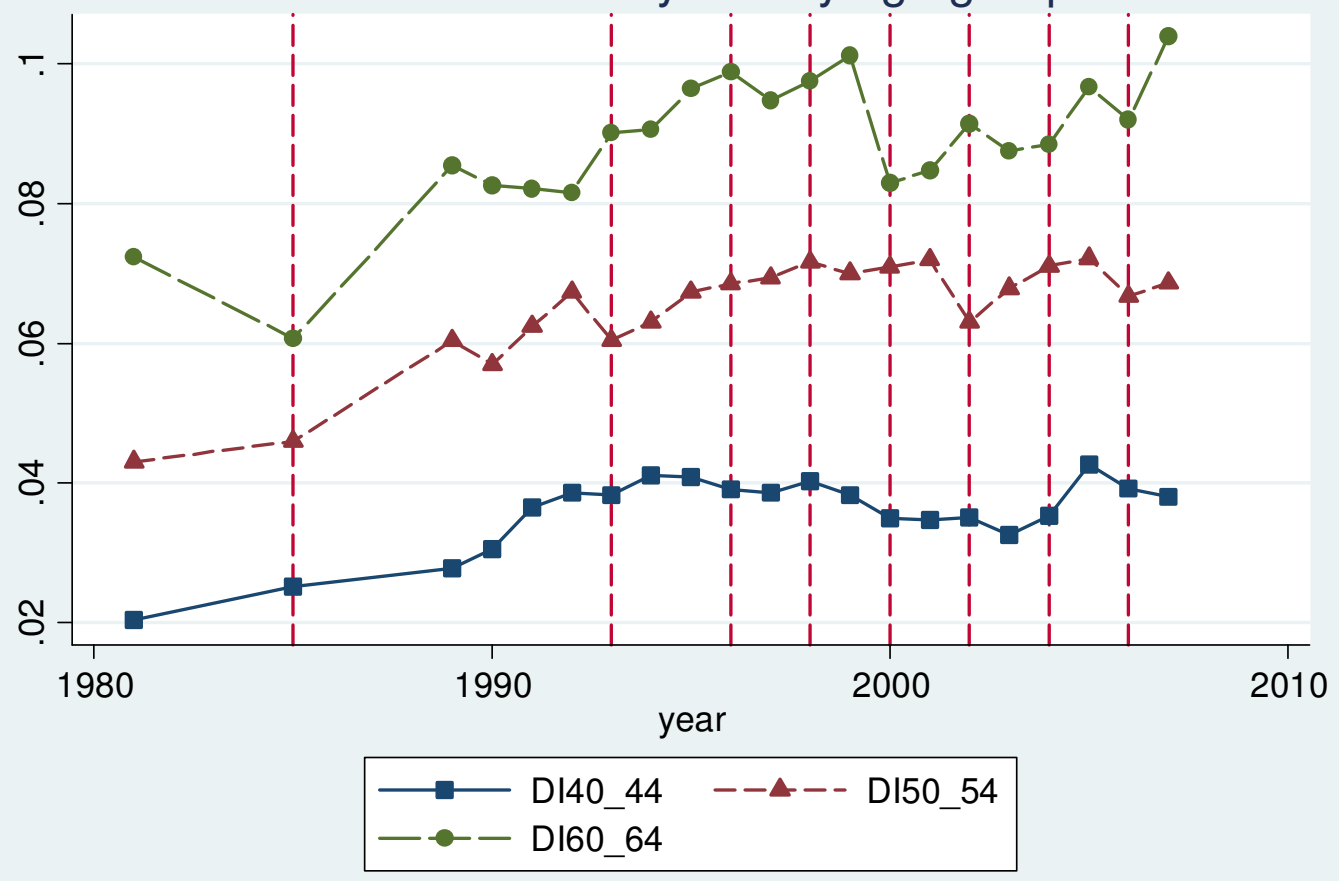


Figure 22

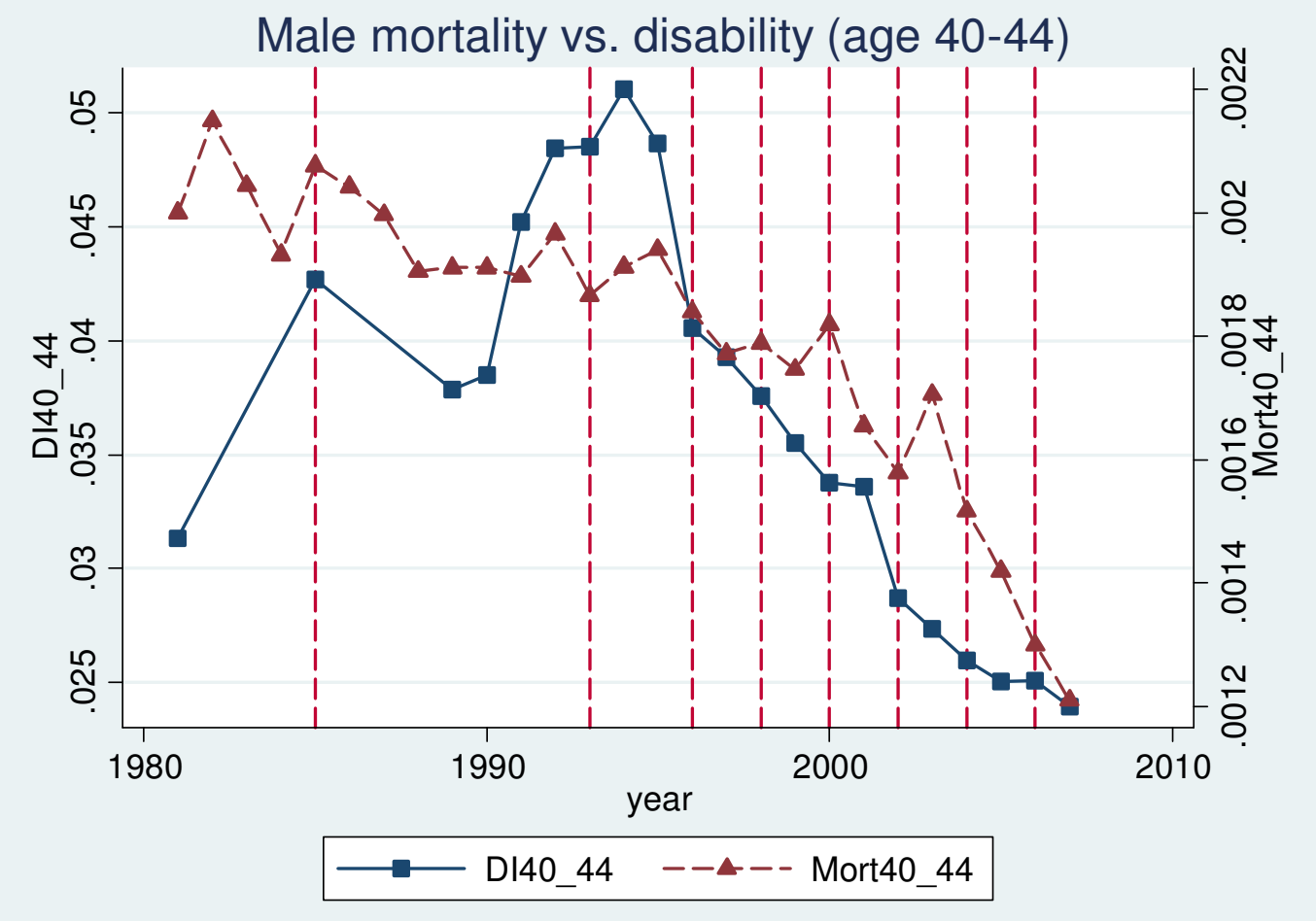

Figure 23

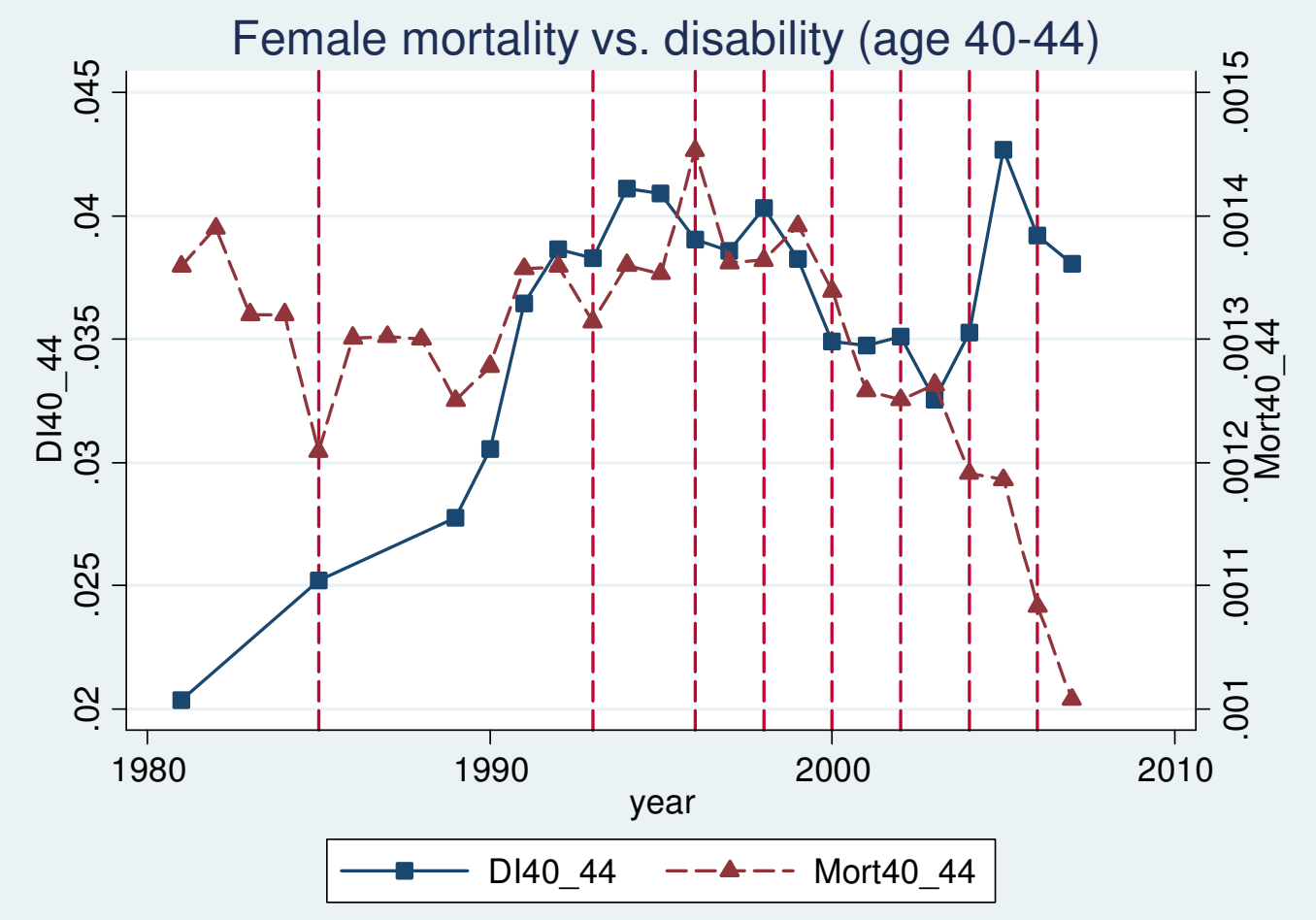


Figure 24

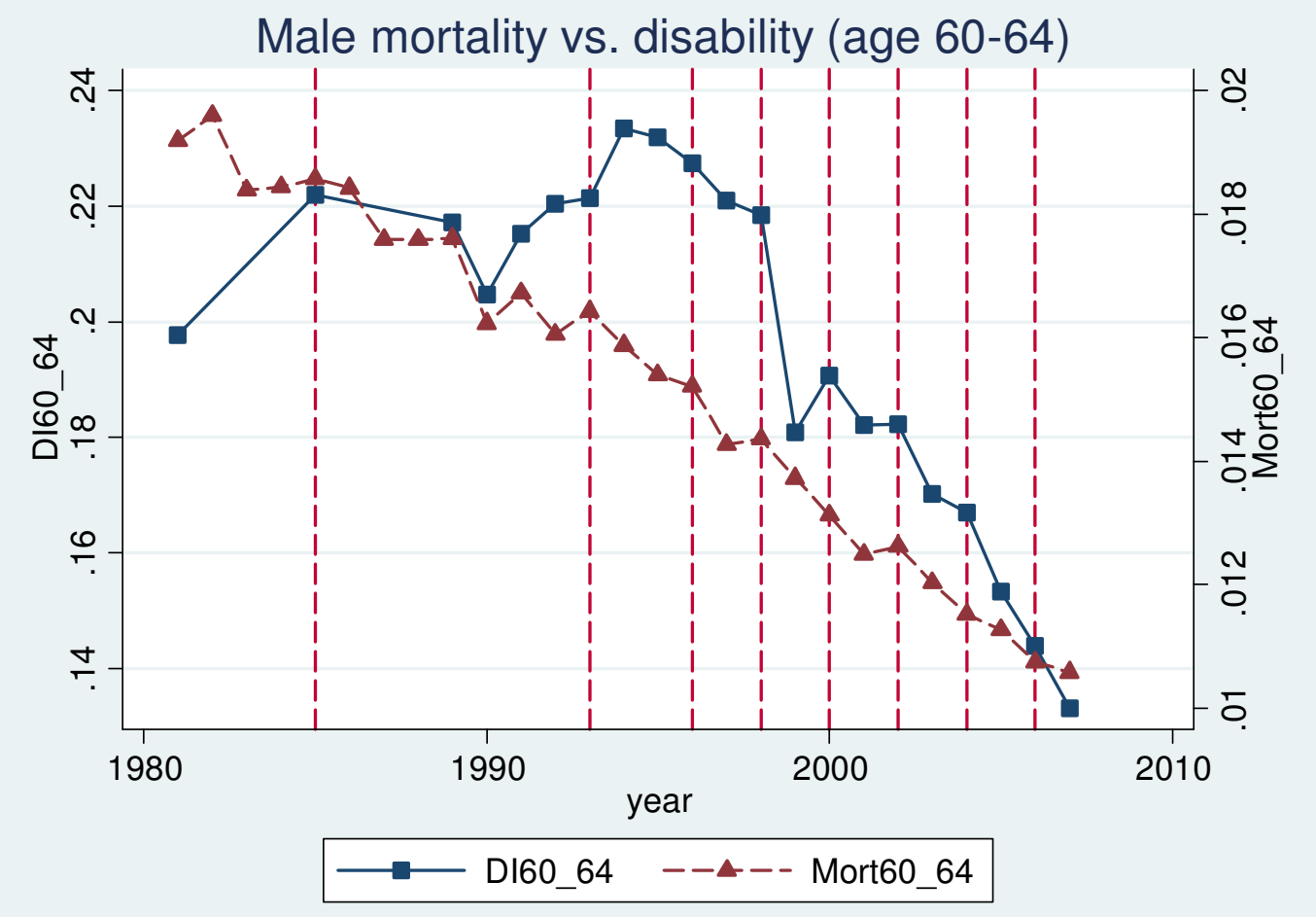

Figure 25

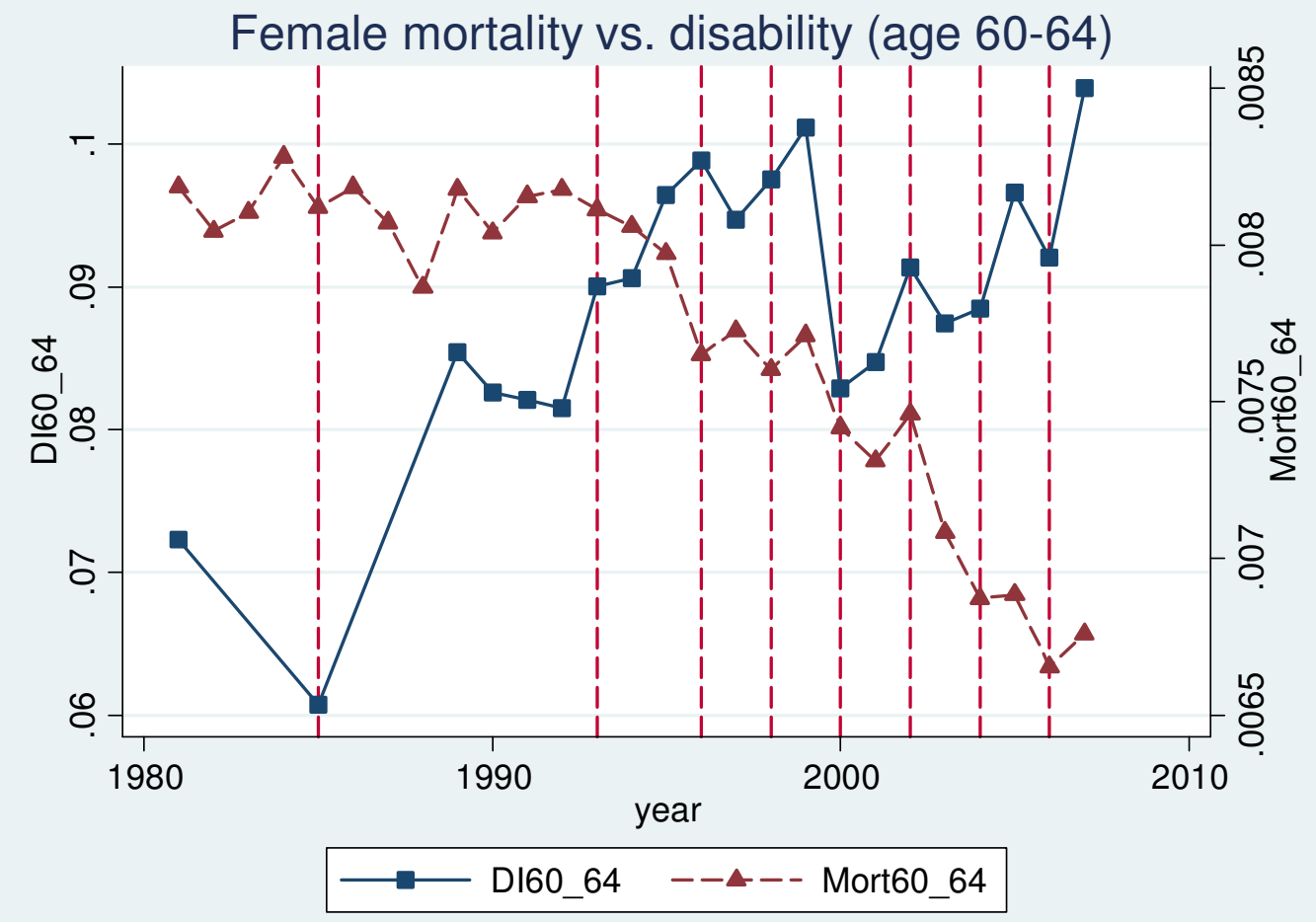


Figure 26

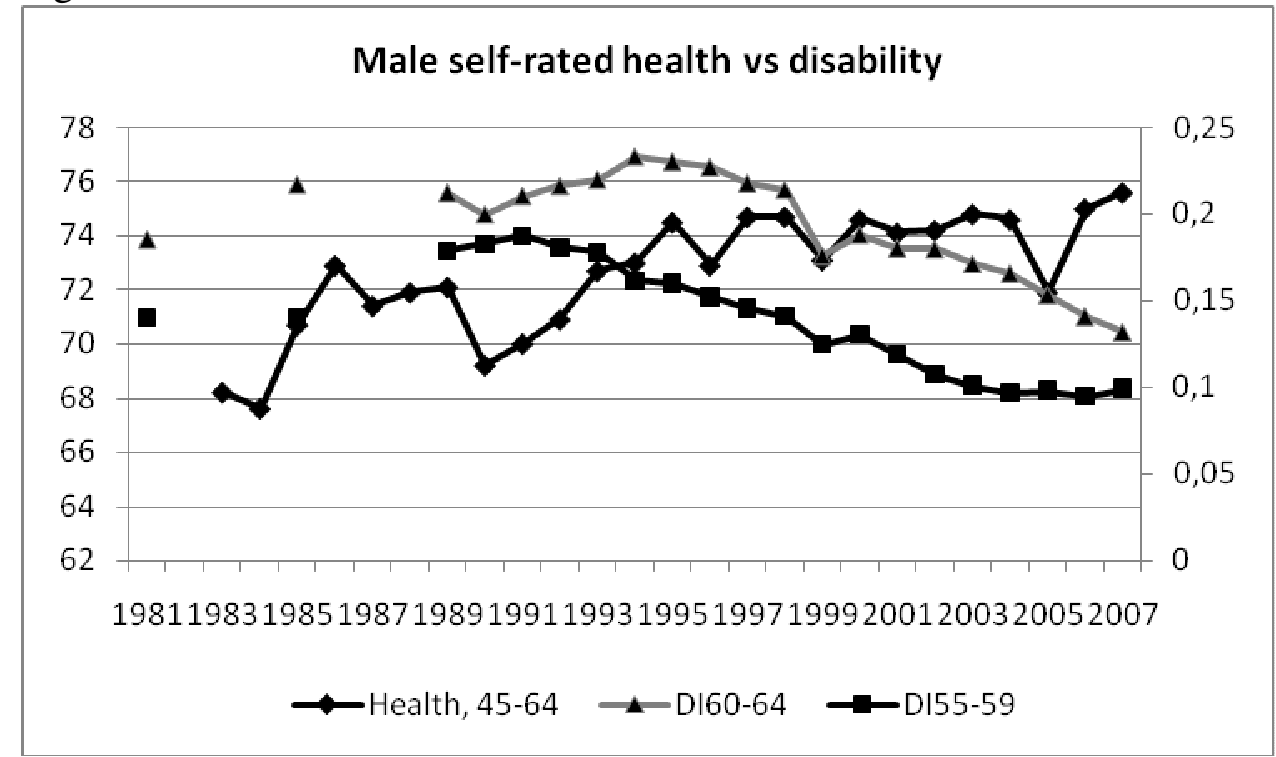

Figure 27

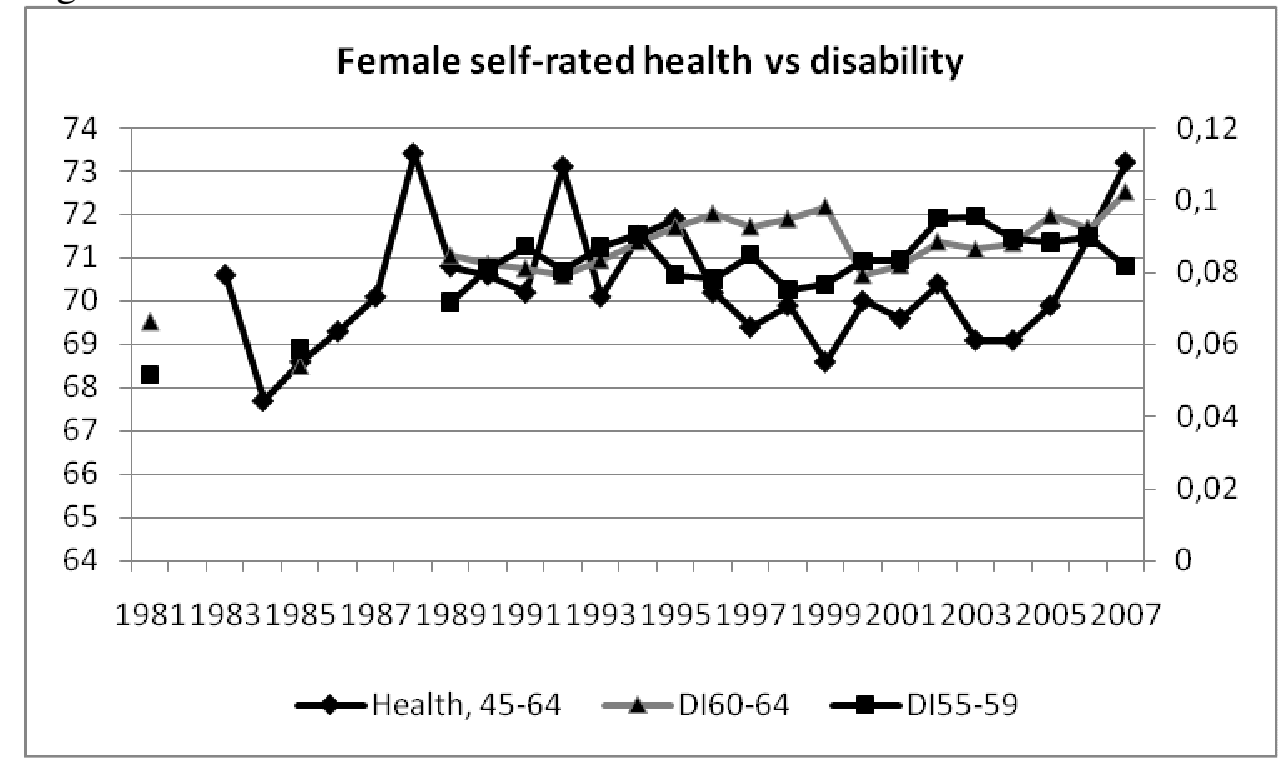


Figure 28

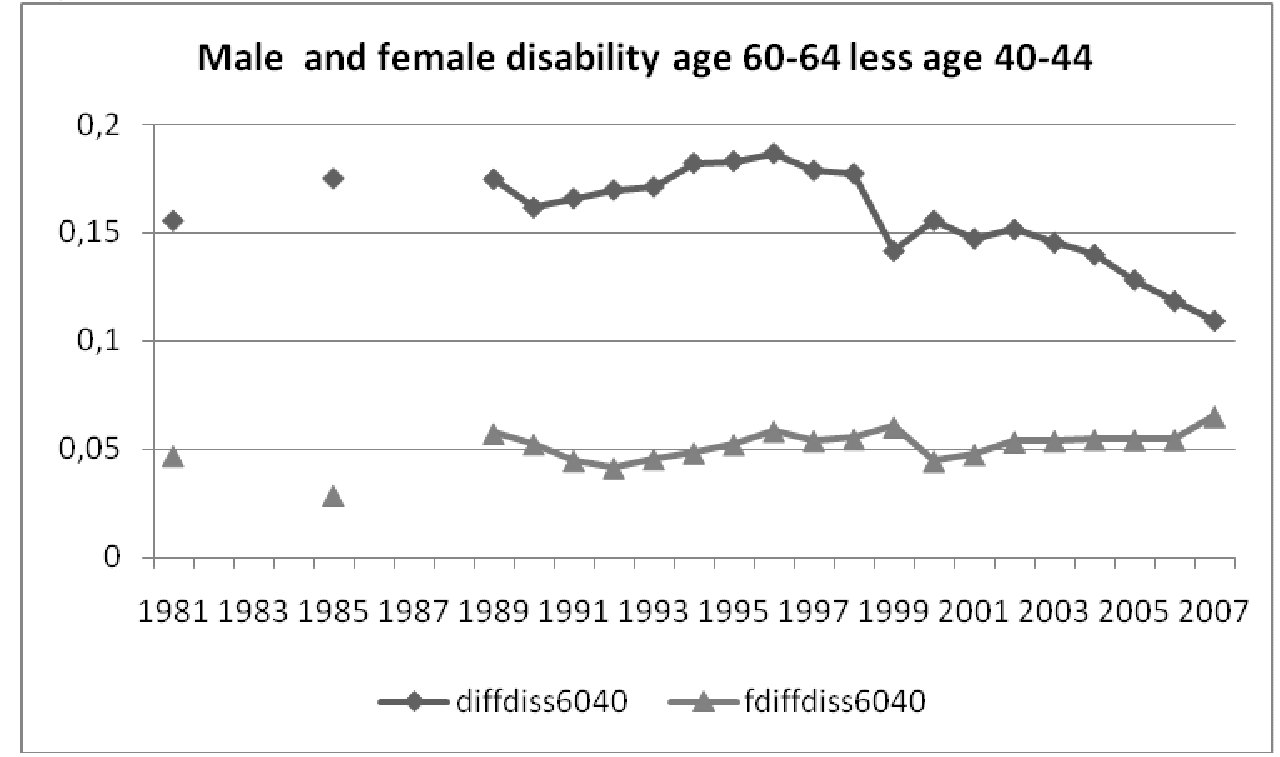


Table 1: Timeline reforms to Disability Insurance (DI), State Pension (SP), Early Retirement (ER), Occupational Pension (PP) and Unemployment Insurance (UI)

\begin{tabular}{|c|c|c|}
\hline & DI / (long-term) Sickness Insurance & SP, ER, PP, UI \\
\hline 1967 & $\begin{array}{l}\text { Introduction of DI (WAO) } \\
(20,000 \text { beneficiaries expected })\end{array}$ & \\
\hline 1974 & & $\begin{array}{l}\text { SP: Benefit raised and linked to net minimum } \\
\text { wage }\end{array}$ \\
\hline $1975-82$ & & $\begin{array}{l}\text { ER: Gradual introduction by } \\
\text { sector/firm/department; } \\
\text { ER: } 1980 \text { ER contribution tax deductible }\end{array}$ \\
\hline 1985 & $\begin{array}{l}764,000 \text { beneficiaries, replacement rate } \\
\text { reduced from } 80 \text { to } 70 \%\end{array}$ & $\begin{array}{l}\text { UI: Replacement rate reduced to } 70 \% \\
\text { SP: Married women get independent claim }\end{array}$ \\
\hline 1987 & $\begin{array}{l}\text { No more (full) DI for (partially) } \\
\text { unemployed }\end{array}$ & $\begin{array}{l}\text { UI: Changes in eligibility and benefit period } \\
\text { Earnings related benefit followed by } \\
\text { continuation benefit } \\
\text { SP: Distinction between married and cohabiting } \\
\text { couples abolished } \\
\text { SP: Introduction single parent allowance }\end{array}$ \\
\hline 1988 & & $\begin{array}{l}\text { SP: Earnings tested supplement when partner is } \\
\text { younger than } 65\end{array}$ \\
\hline 1991 & & UI: Eligibility revised \\
\hline 1993 & $\begin{array}{l}\text { (i) Persons younger than } 50 \text { receive DI for } \\
\text { a limited period } \\
\text { (ii) Stricter disability criteria. } \\
\text { (iii) Retesting of younger DI recipients }\end{array}$ & \\
\hline 1994 & $\begin{array}{l}\text { Introducing employer paid periods of } \\
\text { sickness ( } 2-6 \text { weeks) }\end{array}$ & SP: Earnings tested supplement adapted \\
\hline 1995 & & $\begin{array}{l}\text { UI: Eligibility revised, introduction short term } \\
\text { benefit }\end{array}$ \\
\hline 1996 & $\begin{array}{l}\text { (i) Sickness benefit privatised: employer } \\
\text { pays } 70 \% \text { of earnings ( } 1 \mathrm{yr} \text { ) } \\
\text { (ii) Exemptions for earnings tested } \\
\text { supplement abolished }\end{array}$ & \\
\hline 1998 & $\begin{array}{l}\text { (i) Introduction of (limited) experience } \\
\text { rating DI contributions employer. } \\
\text { (ii) Public employees included in DI } \\
\end{array}$ & \\
\hline $2000-05$ & & $\begin{array}{l}\text { ER/PP: Trend towards actuarially fairer flexible } \\
\text { ER age }\end{array}$ \\
\hline 2001 & & UI: Public employees included \\
\hline 2002 & $\begin{array}{l}\text { Stricter reintegration rules in case of } \\
\text { sickness }\end{array}$ & \\
\hline 2003 & $\begin{array}{l}\text { Experience rating for small employers } \\
\text { abolished }\end{array}$ & UI: Abolition of continuation benefit \\
\hline 2004 & $\begin{array}{l}\text { (i) Sickness benefit period extended to } 2 \\
\text { years } \\
\text { (ii) Strict reevaluation DI recipients } \\
\text { younger than } 50\end{array}$ & \\
\hline 2006 & $\begin{array}{l}\text { Introduction of new DI: strict distinction } \\
\text { between partially and fully, permanently } \\
\text { disabled }\end{array}$ & $\begin{array}{l}\text { ER: Fiscal friendly treatment of ER contributions } \\
\text { repealed; (Introduction of life course saving) } \\
\text { UI: benefit period shortened, higher benefit first } \\
\text { two months }\end{array}$ \\
\hline 2008 & Experience rating DI abolished & \\
\hline
\end{tabular}

Main Source: Kroniek van de sociale verzekeringen 2008, www.uwv.nl 


\begin{tabular}{|c|c|c|c|c|}
\hline \multirow[t]{2}{*}{ Dependent variable } & \multirow[t]{2}{*}{$\begin{array}{l}\text { Ln(total } \\
\text { outflow from } \\
\text { employment) }\end{array}$} & $\ln (\mathrm{P}($ pathy & vay c)/(1-P(pathw & (ay c))) \\
\hline & & $\begin{array}{l}\text { Disability } \\
\text { Insurance } \\
\text { b/t }\end{array}$ & $\begin{array}{l}\text { Early retirement } \\
\mathrm{b} / \mathrm{t}\end{array}$ & $\begin{array}{l}\text { Unemployment } \\
\text { Insurance } \\
\mathrm{b} / \mathrm{t}\end{array}$ \\
\hline Intercept & $\begin{array}{l}0.279 * * \\
(3.54)\end{array}$ & $\begin{array}{l}-0.745 * * \\
(-4.20)\end{array}$ & $\begin{array}{l}-1.683 * * \\
(-13.36)\end{array}$ & $\begin{array}{l}-0.792 * * \\
(-3.30)\end{array}$ \\
\hline Woman & $\begin{array}{l}0.307 * * \\
(2.38)\end{array}$ & $\begin{array}{l}-0.688 * * \\
(-5.48)\end{array}$ & $\begin{array}{l}-0.468 * * \\
(-4.26)\end{array}$ & $\begin{array}{l}-0.477 * * \\
(-3.11)\end{array}$ \\
\hline Age $55-59^{\mathrm{a}}$ & $\begin{array}{l}0.745^{* *} \\
(3.38)\end{array}$ & $\begin{array}{l}-0.568 * * \\
(-2.13)\end{array}$ & $\begin{array}{l}1.398 * * \\
(8.39)\end{array}$ & $\begin{array}{l}-0.496^{*} \\
(-1.73)\end{array}$ \\
\hline Age $60-63^{a}$ & $\begin{array}{l}1.493 * * \\
(2.56)\end{array}$ & $\begin{array}{l}-1.078 \\
(-1.55)\end{array}$ & $\begin{array}{l}3.021 * * \\
(7.01)\end{array}$ & $\begin{array}{l}-2.163 * * \\
(-2.52)\end{array}$ \\
\hline $\ln ($ healthy life expectancy) & $\begin{array}{l}-0.47 \\
(-0.54)\end{array}$ & $\begin{array}{l}1.25 \\
(0.68)\end{array}$ & $\begin{array}{l}0.892 \\
(0.81)\end{array}$ & $\begin{array}{l}-0.732 \\
(-0.29)\end{array}$ \\
\hline 1993, Stricter DI criteria & $\begin{array}{l}0.055 \\
(0.58)\end{array}$ & $\begin{array}{l}-0.433 * * \\
(-2.58)\end{array}$ & $\begin{array}{l}-0.317 * * \\
(-2.72)\end{array}$ & $\begin{array}{l}0.637 * * \\
(3.75)\end{array}$ \\
\hline 1996, DI,1 year sickness benefits & $\begin{array}{l}-0.241 * * \\
(-2.52)\end{array}$ & $\begin{array}{l}0.234 \\
(1.54)\end{array}$ & $\begin{array}{l}0.091 \\
(0.77)\end{array}$ & $\begin{array}{l}-0.364 * * \\
(-2.75)\end{array}$ \\
\hline 1998, Experience rating employer & $\begin{array}{l}0.112 \\
(1.13)\end{array}$ & $\begin{array}{l}0.386^{* *} \\
(2.80)\end{array}$ & $\begin{array}{l}-0.285^{* *} \\
(-2.11)\end{array}$ & $\begin{array}{l}-0.652 * \\
(-1.75)\end{array}$ \\
\hline 2000, ER actuarially fairer & $\begin{array}{l}-0.073 \\
(-0.68)\end{array}$ & $\begin{array}{l}-0.297 * * \\
(-2.36)\end{array}$ & $\begin{array}{l}0.231 * \\
-1.8\end{array}$ & $\begin{array}{l}0.22 \\
-1.06\end{array}$ \\
\hline 2002, DI, gatekeeper improvement & $\begin{array}{l}-0.056 \\
(-0.64)\end{array}$ & $\begin{array}{l}-0.345 * * \\
(-2.44)\end{array}$ & $\begin{array}{l}-0.008 \\
(-0.07)\end{array}$ & $\begin{array}{l}0.256 \\
(1.53)\end{array}$ \\
\hline 2004, DI,2 years sickness benefits & $\begin{array}{l}0.022 \\
(0.27)\end{array}$ & $\begin{array}{l}0.031 \\
(0.20)\end{array}$ & $\begin{array}{l}-0.083 \\
(-0.71)\end{array}$ & $\begin{array}{l}0.089 \\
(0.50)\end{array}$ \\
\hline 2006, new DI (WIA), ER/UI changes & $\begin{array}{l}-0.292^{*} \\
(-1.70)\end{array}$ & $\begin{array}{l}-0.259 \\
(-1.50)\end{array}$ & $\begin{array}{l}0.114 \\
(0.85)\end{array}$ & $\begin{array}{l}0.051 \\
(0.32)\end{array}$ \\
\hline $\operatorname{Ln}(\text { level of employment })^{b}$ & $\begin{array}{l}0.896 * * \\
(4.62)\end{array}$ & & & \\
\hline Ln(total outflow from employment) & & $\begin{array}{l}0.221 \\
(0.63)\end{array}$ & $\begin{array}{l}0.769 * * \\
(2.28)\end{array}$ & $\begin{array}{l}-0.003 \\
(-0.00)\end{array}$ \\
\hline${\text { Exogeneity test }(p-v a l u e)^{c}}^{c}$ & & $0.049 * *$ & 0.779 & 0.573 \\
\hline $\begin{array}{l}\text { Test for the explanatory power of the } \\
\text { additional instrument (p-value) }{ }^{d}\end{array}$ & $0.000 * *$ & & & \\
\hline R-squared & 0.656 & 0.755 & 0.945 & 0.76 \\
\hline Number of observations & 108 & 108 & 108 & 108 \\
\hline
\end{tabular}
$* \mathrm{p}<0.10, * * \mathrm{p}<0.05$
a) Reference age 50-54. The age dummies are jointly significant (p-value F-test is 0.001 )
b) OECD statistics, by age and gender.
c) $\mathrm{H}_{0}$ : total outflow from employment is exogenous.
d) The null-hypothesis is that the additional instrument $\operatorname{Ln}($ level of employment) has no explanatory power. 
Table 3: Predicted changes in the pathway probabilities

\begin{tabular}{|c|c|c|c|c|c|c|c|c|c|c|}
\hline & \multicolumn{10}{|c|}{ Pathway } \\
\hline & \multicolumn{2}{|c|}{$\begin{array}{l}\text { Total outflow from } \\
\text { employment }\end{array}$} & $\begin{array}{l}\text { Disability } \\
\text { Insurance }\end{array}$ & & $\begin{array}{l}\text { Early } \\
\text { Retirement }\end{array}$ & \multicolumn{3}{|c|}{$\begin{array}{l}\text { Unemployment } \\
\text { Insurance }\end{array}$} & \multicolumn{2}{|c|}{ Non-Participation } \\
\hline & \multicolumn{2}{|c|}{$\%$} & $\%$ & & $\%$ & \multicolumn{3}{|c|}{$\%$} & \multicolumn{2}{|c|}{$\%$} \\
\hline Probability of outflow for the reference group ${ }^{\text {a) }}$ & \multicolumn{2}{|l|}{3.46} & 32.84 & & 15.23 & \multicolumn{3}{|c|}{31.29} & \multicolumn{2}{|l|}{20.64} \\
\hline \multirow[t]{2}{*}{ Cells: Predicted changes } & prediction & t-value & \multicolumn{8}{|c|}{ prediction $\mathrm{t}$-value prediction $\mathrm{t}$-value prediction $\mathrm{t}$-value prediction $\mathrm{t}$-value } \\
\hline & \multicolumn{2}{|l|}{$\%$-change } & $\%$-change & & $\%$-change & \multicolumn{2}{|c|}{ \%-change } & \multicolumn{3}{|c|}{ \%-change } \\
\hline Women relative to men & 35.91 & 2.05 & -40.17 & -6.72 & -33.49 & -5.27 & -29.60 & -3.50 & 133.54 & 5.25 \\
\hline Age $55-59$, relative to age $50-54$ & 110.69 & 2.38 & -34.16 & -2.53 & 173.84 & 5.96 & -30.64 & -2.05 & -27.47 & -0.13 \\
\hline Age $60-63$, relative to age $50-54$ & 345.17 & 1.33 & -56.81 & -2.25 & 405.39 & 5.43 & -84.11 & -6.88 & -81.22 & -0.90 \\
\hline A $10 \%$ increase in healthy life expectancy & -4.60 & -0.55 & 8.66 & 0.65 & 7.76 & 0.78 & -4.96 & -0.30 & -11.98 & 0.79 \\
\hline A $10 \%$ increase in the flow out of employment & & & 1.51 & 0.62 & 6.66 & 2.14 & -0.02 & 0.00 & -7.28 & -3.10 \\
\hline The cumulative effect of the reforms ${ }^{\text {b) }}$ & -37.70 & -2.33 & -39.97 & -2.61 & -19.87 & -1.12 & 16.92 & 0.50 & 52.63 & 1.54 \\
\hline
\end{tabular}

a) Men aged 50-54 in 1989

b) The reforms listed in table 1 and included in the analysis (table 2). 